$\begin{array}{r}\text { Bartın Üniversitesi } \\ \text { Eğitim Fakültesi Dergisi }\end{array}$
Cilt 5, Sayı 3, s. 764-787, Ekim 2016
BARTIN - TÜRKIYE $\begin{aligned} & \text { Bartin University } \\ & \text { Journal of Faculty of Education } \\ & \text { Volume 5, Issue 3, p. 764-787, 0ctober } 2016 \\ & \text { BARTIN - TURKEY }\end{aligned}$

Doi: 10.14686/buefad.v5i3.5000201236

\title{
Açık Öğretim Lisesi Öğrencisi Hükümlü ve Tutukluların Okumaya Yönelik Tutumları
}

\author{
Hatice ALTUNKAYA, Yrd. Doç. Dr. Adnan Menderes Üniversitesi Eğitim Fakültesi, hatice.altunkaya@adu.edu.tr
}

Öz: Bu çalışmanın amacı, Açık Öğretim Lisesi öğrencisi hükümlü ve tutukluların okuma tutum düzeylerini çeşitli değişkenlere göre belirlemektir. Araştırma, nicel ve nitel veri analiz tekniklerinin birlikte kullanıldığı karma araştırma modeline göre yürütülmüştür. Araştırmada nicel araştırma yöntemlerinden tarama yöntemi, nitel araştırma yöntemlerinden ise odak grup görüşmesi tekniği kullanılmıştır. Araştırmanın çalışma grubunu, Silivri 7 No'lu L tipi 78, Bilecik M tipi 73 ve Uşak E tipi Kapalı Ceza İnfaz Kurumundan 67 öğrenci olmak üzere toplam 211 hükümlü ve tutuklu Açık Öğretim Lisesi öğrencisi oluşturmuştur. Nicel veriler Özdemir ve Akkaya (2014) tarafından geliştirilen "Okumaya Yönelik Tutum Ölçeği" ve "Kişisel Bilgi Formu" ile nitel veriler odak grup görüşmesi ile elde edilmiştir. Nicel verilerin analiz edilmesinde SPSS 22 veri analiz programı, nitel verilerin analizinde ise içerik analizi yöntemi kullanılmıştır. Araştırma sonucunda öğrencilerin "yarar" düzeyi çok yüksek "adanma" düzeyi yüksek; "alışkanlık" düzeyi yüksek; "gerçeği aşma" düzeyi çok yüksek; "okuma tutum genel" düzeyi yüksek olarak saptanmıştır. 31-35 yaş arası öğrencilerin yarar puanlarının 25 yaş altı, 26-30 ve 36-40 yaş arasında olanlardan yüksek olduğu tespit edilmiştir. Uşak Kapalı Ceza İnfaz Kurumunda bulunan öğrencilerin adanma ve yarar boyutunda Bilecik ve Silivri 7 No'luda bulunan öğrencilerden daha yüksek puana sahip olduğu, gerçeği aşma boyutunda Uşak'ta bulunan öğrencilerin puanlarının Bilecik'te bulunanlardan yüksek olduğu, okumaya yönelik tutum genel puanında yine Uşak'ta bulunanların puanının diğer iki kurumdakilerden yüksek olduğu görülmüştür. Akdeniz, Ege ve Güneydoğu Anadolu bölgesinden olan öğrencilerin adanma puanlarının Marmara ve Karadeniz bölgesinde olanlarınkinden yüksek olduğu tespit edilmiştir. Grup görüşmeleri neticesinde ise öğrencilerin tutukluluk durumları sonrasında okumaya yönelik tutumlarının olumlu yönde geliştiği, ceza infaz kurumu eğitim birimleri ve kütüphane çalışmalarının kendilerine büyük katkı sağladığı sonucuna ulaşılmıştır.

Anahtar Kelimeler: ceza infaz kurumu, okuma tutumu, hükümlü, tutuklu, açık öğretim lisesi.

\section{Convict and Arrested Students' Attitudes towards Reading in Distance Secondary School Education}

Abstract: This study is intended to identify the level of reading attitudes of convict and arrested students in Distance Secondary School Education, based on different variables. The study is conducted according to a mixed survey model where quantitative and qualitative data analysis techniques are employed together. The study used the screening method of quantitative survey methods and focus group interview technique of the quantitative survey methods. The study group in the survey is made up of a total of 211 convict and arrested students in Distance Secondary School Education; 78 from Silivri No.7 Type L Closed Prison, 73 from Bilecik Type M and 67 from Uşak Type E Closed Prisons. Quantitative data is obtained via the "Attitude Towards Readindg Scale" developed by Özdemir and Akkaya (2014) and "Personal Data Form" while the qualitative data is obtained through the focus group interview. SPSS 22 data analysis program is employed in the analysis of quantitative data while content analysis method is used in the analysis of the qualitative data. Based on the survey, the "benefit" level of the students is identified as very high; the "commitment" level as high; the "habit" level as high; the "beyond reality" as very high; the "overall reading attitude" as high. The benefit levels of the students aged between 31-35 is found out to be higher than those aged below 25, between 26-30 and 36-40. It is seen that the students in Uşak Closed Prison has had higher points in the extent of 'commitment and benefit', as opposed to the students in Bilecik and Silivri No.7; the students in Uşak has had higher points in the extent of 'beyond reality, as opposed to those in Bilecik; and again those in Uşak has had higher points overall in the attitude towards reading, as compared to those in other two institutions. The commitment points of the students in Mediterranean Aegean and South Eastern Regions are found out to be higher than those in Marmara and Black Sea Regions. Based on the interviews carried out, it is concluded that the attitudes of the students towards reading have changed positively following their imprisonment and the training units and library activities in the department of corrections have made a great deal of contributions to them.

Key Words: department of corrections, reading attitude, convicted, arrested, distance secondary school. 


\section{GíRiş}

Hayat Boyu Öğrenme Genel Müdürlüğü bünyesinde eğitim öğretim faaliyetlerini sürdüren Açık Öğretim Lisesi (AÖL) 1992 yılında kurulan ve uzaktan öğretim teknolojilerini kullanarak lise öğrenimi veren bir sistemdir. Açık Öğretim Lisesinde örgün eğitimdeki genel liselerin program içerikleriyle aynı eğitim gerçekleştirilmekte, ortak ve seçmeli dersler Talim Terbiye Kurulu Başkanlığı tarafından örgün öğretime paralel olarak belirlenmektedir. AÖL'de 2015-2016 eğitim öğretim yılı birinci döneminde aktif olarak kayıtı öğrenci sayısı 592308 kadın, 434474 erkek olmak üzere toplam 1026782'dir (http://www.aol.meb.gov.tr/aolsayisalveriler.php?cgl=8). Bu öğrencilerin bir bölümünü Adalet Bakanlığına bağlı ceza infaz kurumlarında barındırılan hükümlü ve tutuklular oluşturmaktadır.

Adalet Bakanlı̆̆ı Ceza ve Tevkifevleri Genel Müdürlüğü 27/07/2007 tarihinde "ceza infaz kurumlarında genç ve yetişkin hükümlü ve tutuklulara uygulanacak eğitim ve iyileştirme çalışmalarına ilişkin usul ve esasları göstermek, mevzuatın uygulanmasını kolaylaştırmak ve uygulamada ortaya çıkan sorunları gidermek amacıyla" 46/1 no'lu genelgeyi uygulamaya koymuştur (http://www.cte.adalet.gov.tr/). Söz konusu genelgede eğitim ilkeleri aşağıdaki şekilde belirtilmiştir:

(1) Hükümlü ve tutukluların maddî ve manevî kalkınmaları için eğitim ve öğretim faaliyetlerinin gerekliliği ve yararı bütün dünyaca kabul edilmiştir. Bu faaliyetler, en etkili iyileştirme aracı olduğu kadar, kurum rejiminin gerektirdiği disiplin ve düzene en iyi uyan yaşayış sistemidir.

(2) Eğitime yönelik çalışmalardan beklenen; hükümlü ve tutukluların doğru davranış, tutum ve alışkanlıkları benimseyerek, yeniden suç işlemelerini önleyecek ahlâkî değerler kazanmalarını sağlamak, kurum hayatını normal hayata yakınlaştırarak, bu kişilerin salıverilmelerinden sonra topluma uyumlarını kolaylaştırmak ve dış olaylara, tahriklere karşı sabırlı, dayanıklı ve soğukkanlı hâle getirmektir.

(3) Avrupa Konseyi Bakanlar Komitesinin R (89) 12 sayılı "Ceza Infaz Kurumlarındaki Eğitim" konulu tavsiye kararı ile ceza infaz kurumlarındaki eğitim hakkında üye devletlerce benimsenmesi önerilen aşağıdaki temel ilkelere uyulur;

a) Bütün hükümlü ve tutukluların, meslekî eğitim, yaratıcı ve kültürel faaliyetler, bedensel eğitim, spor, sosyal eğitim ve kütüphane tesislerini intiva edecek şekilde tasarlanmış bir eğitime sahip olması sağlanacaktır.

b) Hükümlü ve tutuklulara verilecek eğitimin, dış dünyada aynı yaş gruplarına sağlanan eğitimle aynı olması sağlanacak ve öğrenme fırsatlarının alanı olabildiğince geniş tutulacaktır.

c) Ceza infaz kurumlarında eğitim; kişinin sosyal, ekonomik ve kültürel şartlarını akılda tutarak onu bir bütün hâlinde geliştirmeyi hedefleyecektir.

c) Ceza infaz kurumları sisteminin yönetimine katılanların ve ceza infaz kurumlarını yönetenlerin hepsi eğitimi mümkün olabildiğince daha fazla destekleyecek ve kolaylaştıracaktır.

d) Hükümlü ve tutukluların, eğitimin bütün yönlerine aktif olarak katılmasını teşvik etmek için her türlü çaba gösterilecektir.

e) Ceza infaz kurumları eğitimcilerinin, uygun yetişkin eğitim metotlarını benimsemelerinin sağlanması için geliştirme programları temin edilecektir.

f) Özel zorlukları olan hükümlü ve tutuklulara ve özellikle okuma yazma problemi olanlara özel itina gösterilecektir.

g) Meslekî eğitim, bireyin daha geniş olarak geliştirilmesine olduğu kadar, iş piyasasındaki intiyaçlar da dikkate alınarak düzenlenecektir. 
h) Hükümlü ve tutuklular haftada en az bir kez, iyi düzenlenmiş bir kütüphaneye gidebilmelidir.

ı) Hükümlü ve tutukluların beden eğitimi çalışmaları yapmaları ve spor faaliyetlerine katılmaları teşvik edilmelidir.

i) Yaratıcı ve kültürel faaliyetlere önemli bir rol verilecektir. Çünkü bu faaliyetler hükümlü ve tutukluların kendilerini ifade etmelerinde ve geliştirmelerinde özel bir potansiyele sahiptir.

j) Sosyal eğitim, topluma geri dönmesini kolaylaştırmak amacıyla, hükümlü ve tutukluların ceza infaz kurumlarındaki günlük yaşamını idare etmesini sağlayacak uygulanabilir unsurları içine almalıdır.

k) Mümkün olan her durumda hükümlülerin ceza infaz kurumları dışında eğitime katılmasına izin verilmelidir.

I) Eğitimin ceza infaz kurumları içerisinde verilmesi gereken hâllerde, kurum dışından da destek alınmalıdır.

m) Hükümlü ve tutukluların salıverilme sonrasında da eğitimlerine devam etmelerini sağlayacak tedbirler alınmalıdır.

n) Hükümlü ve tutukluların uygun eğitim almalarını sağlayacak malî kaynak, alet, donanım ve öğretim personeli hazır bulundurulmalıdır.

Ülke genelinde tüm ceza infaz kurumlarında bu eğitim ilkeleri doğrultusunda hükümlü ve tutuklulara eğitimler verilmektedir. Açık Öğretim Lisesi de bu eğitimlerden biridir ve Ceza Tevkifevleri Genel Müdürlüğünün ceza infaz kurumlarına gönderdiği 14/12/2015 tarih ve 2852/184245 sayılı yazıdan edinilen bilgiye göre 2015-2016 eğitim öğretim yılı birinci dönemi itibariyle Türkiye ceza infaz kurumlarında toplam 17857 öğrenci aktif AÖL öğrencisi olarak kayıtlı bulunmaktadır. Hükümlü ve tutuklular öğrenci olmaları nedeniyle öncelikle ders kitaplarını okumak durumundadırlar. Bulundukları ortamda okumaya yönelik olumlu ya da olumsuz tavırları, davranışları, düşünceleri okumaya yönelik tutumlarını gösterir.

Bireylerin herhangi bir olay, durum, kişiye karşı bilişsel, duyuşsal ve davranışsal olarak sergiledikleri tavır şekli tutumu oluşturur. Birey bir durum, olay veya kişi karşısında öncelikle bilişsel ve duyuşsal özelliklerinin birleşimiyle bir düşünce oluşturur ve bu düşüncesini davranışsal olarak ortaya koyduğunda bu davranış biçimi onun tutumunu gösterir. "Başlangıçta sosyal psikolojinin konusu ve anahtar kavramlarından birisi olarak ortaya çıkan tutumlar, zamanla hem kuramsal gelişmeler hem de yöntem açısından kaydedilen ilerlemeler neticesinde birçok bilim dalının yanında eğitim bilimlerinin de araştırma alanına girmiştir" (Temizkan, 2008: 463). Tutum, bireyin kendine ya da çevresindeki herhangi bir nesne, toplumsal konu ya da olaylara karşı deneyim, bilgi, duygu ve güdülerine (motivasyon) dayanarak örgütlediği zihinsel, duygusal ve davranışsal bir tepki ön eğilim (İnceoğlu, 2010: 13), yaşantı ve deneyimler sonucu oluşan, ilgili olduğu bütün nesne ve durumlara karşı bireyin davranışları üzerinde yönlendirici ya da dinamik bir etkileme gücüne sahip duygusal ve zihinsel hazırlık durumu (Allport, 1967, 4), bireyi belli insanlar, nesneler ve durumlar karşısında belli davranışlar göstermeye iten öğrenilmiş eğilimler (Demirel ve Ün, 1987: 94), bireyin davranışlarını yönlendirmede önemli bir güce sahip, sonradan kazanılmış duygu, düşünce ve eğilimler (Baştuğ ve Keskin, 2013: 296) olarak tanımlanmaktadır. Tutum, bireylerin doğdukları çevreden aldıkları ilk izlenimler, değer yargıları, sosyal ve kültürel yargılar, ön yargılar ile birlikte aldıkları eğitim, geçirdikleri yaşam deneyimi sonucunda kişisel, toplumsal olay ve durumlara karşı duyuşsal, bilişsel ve davranışsal olarak sergiledikleri eğilim, davranış olarak tanımlanabilir. 
Kağıtçıbaşı'na göre (1999) tutum:

- Tutum psikolojik bir objeye ilişkindir,

- Tutumlar tepki vermeye hazır olmayı içermektedir,

- Tutumlar güdüleme gücüne sahiptir,

- Tutumlar durağan olabilir,

- Tutumlar değerlendirme içermektedir,

- Tutumlar doğrudan gözlenebilen bir özellik değil, bireyin gözlenebilen davranışlarından çıkarsama yapılarak ve o bireye atfedilen bir eğilimdir.

Yapılan araştırmalarda okumaya yönelik tutum ile ilgili ölçek geliştirme çalışmaları (Gömleksiz, 2004; Özbay ve Uyar, 2009; McKenna, Conradi, Lawrence, Jang ve Meyer, 2012 Türkçeye uyarlayan Baştuğ ve Keskin, 2013-; Susar Kırmızı ve Güneş, 2014; Türkyılmaz ve Aydemir, 2014), ilköğretim öğrencilerine yönelik betimsel çalışmalar (Sallabaş, 2008; Başaran ve Ateş, 2009; Balcı, 2009; İşeri, 2010; Balcı, Uyar ve Büyükikiz, 2012), ortaöğretim öğrencilerine yönelik betimsel çalışmalar (Baş, 2012; Özdemir, 2013; Akkaya ve Özdemir, 2013; Çeçen ve Deniz, 2015), üniversite öğrencilerine yönelik betimsel çalışmalar (Yalınkılıç, 2007; Yılmaz ve Benli, 2010; Dedeoğlu ve Ulusoy, 2011; Sarar-Kuzu, 2013; Arı ve Demir, 2013; Koçak, Kurtlu, Ulaş ve Epçaçan, 2015), deneysel çalışmalar (Akyol ve Başaran, 2009; iflazoğlu ve Ayçin, 2011; Kanmaz ve Saracaloğlu, 2012; Yaman ve Dağtaş, 2013; Epçaçan, 2013), metaanaliz çalışması (Aydın, Kaya, Bayraktar, 2015) gerçekleştirildiği görülmektedir. Örneklem grubu incelendiğinde ilköğretim, lise ve üniversite öğrencilerine yönelik çalışmaların gerçekleştirildiği, Açık Öğretim Lisesi öğrencilerine yönelik ve hükümlü tutuklu Açık Öğretim Lisesi öğrencilerine yönelik bir çalışma bulunmadığı, okuma alışkanlığı ile ilgili Açık Öğretim Ortaokulu Öğrencilerine yönelik bir çalışma bulunduğu (Erdem, Altunkaya, 2013) görülmektedir. Hükümlü ve tutukluların topluma yeniden kazandırılması, yeniden suç işlemelerinin önüne geçilmesi ancak eğitimle mümkün olabilir. Bu doğrultuda gerçekleştirilecek eğitimlerle hükümlü tutukluların okumaya yönelik tutumlarının iyileştirilmesi, onlara okuma alışkanlığı kazandırılması büyük önem arz etmektedir. Bu eğitimlerin gerçekleştirilebilmesi için öğrencilerin okumaya yönelik tutumlarının bilinmesinde yarar bulunduğu düşünülmektedir.

Araştırmanın amacı, Açık Öğretim Lisesi öğrencisi hükümlü ve tutukluların okumaya yönelik tutum düzeylerini tespit etmek ve bu düzeyleri çeşitli değişkenler doğrultusunda incelemek, ceza infaz kurumlarında sağlanan okuma ortamlarının okuma tutumlarını nasıl etkilediğini ortaya çıkarabilmektir. Bu amaç doğrultusunda aşağıdaki amaçlar, araştırmanın alt problemleri olarak belirlenmiştir:

a) Öğrencilerin okumaya yönelik tutumları genel olarak ne düzeydedir?

b) Öğrencilerin okumaya yönelik tutumları yaş değişkenine göre farklııı göstermekte midir?

c) Öğrencilerin okumaya yönelik tutumları suç türü değişkenine göre farklılık göstermekte midir?

d) Öğrencilerin okumaya yönelik tutumları nereli olduklarına göre farklılık göstermekte midir?

e) Öğrencilerin okumaya yönelik tutumları medeni durum değişkenine göre farklılık göstermekte midir?

f) Öğrencilerin okumaya yönelik tutumları bulundukları ceza infaz kurumuna göre farklılık göstermekte midir?

g) Tutuklanma durumları okumaya yönelik tutumlarına nasıl bir etkide bulunmuştur?

h) Ceza İnfaz Kurumları Eğitim Birimlerinin sağladığı imkânlar okumaya yönelik tutumlarını nasıl etkilemektedir? 
i) AÖL öğrencisi olmaları okumaya yönelik tutumlarında bir değişiklik meydana getirmekte midir?

j) Ceza infaz kurumu ortamında hükümlü ve tutukluların fazla vakte sahip olmaları ve öğrenci olmaları okumayı sevmelerine, okumaya ihtiyaç hissetmelerine neden olmakta mıdır?

k) Ceza infaz kurumu kütüphanelerinde bulunan kitap çeşitliliği okumaya yönelik tutumlarını nasıl etkilemektedir?

\section{YÖNTEM}

\subsection{Araştırma Modeli}

Araştırmada nicel ve nitel verilerin toplanması ve analiz edilmesini içeren karma yöntem araştırması kullanılmıştır. "Karma yöntem araştırması, felsefi varsayımları ve kuramsal çerçeveleri içeren farklı araştırma desenlerinin kullanılmasını, nitel ve nicel verilerin toplanmasını ve bu iki veri türünün bütünleştirilmesini kapsayan bir araştırma yaklaşımıdır" (Creswell, 2013: 4).

Dey (1993), nicel yöntemlerde sayılarla elde edilen verilerin anlamlarını derinlemesine algılayabilmek için nitel veriler kullanımı yoluna gidildiğini ifade etmektedir. Goodson ve Walker'e göre (2005), nitel veriler elde etmek hayatı eğitim araştırmalarının içine çekmektir. "Karma yöntem araştırmalarının önemli özelliklerinden biri de farklı yöntemlerle toplanan verilerin birbirini doğrulama amacıyla kullanılması ve bu şekilde sonuçlardaki inandırıcılığın daha güçlü olmasıdır" (Yıldırım ve Şimşek, 2013).

Araştırmanın, nicel kısmında tarama modellerinden genel tarama modeli, nitel kısmında ise odak grup görüşmesi tekniği esas alınmıştır.

\section{2. Çalışma Grubu}

Araştırmanın nicel kısmının çalışma grubunda 2015-2016 eğitim öğretim yılında öğrenim gören 67 Bilecik M Tipi Kapalı Ceza İnfaz Kurumunda, 84 Silivri 7 No'lu L Tipi Kapalı Ceza Infaz Kurumunda ve 60 Uşak E Tipi Kapalı Ceza İnfaz Kurumunda barındırılan AÖL öğrencisi olmak üzere toplam 211 öğrenci bulunmaktadır. Katılımcıların tamamı erkektir. Araştırmanın nitel kısmının çalışma grubunda Silivri 7 No'lu L Tipi Kapalı Ceza İnfaz Kurumundan 8 AÖL öğrencisi hükümlü ve tutuklu yer almaktadır. Araştırmaya katılan öğrencilere ilişkin tanımlayıcı bilgiler aşağıdaki tabloda yer almaktadır:

\section{Tablo 1}

Çalıșma Grubuna Ait Tanımlayıcı Özelliklerin Dağııımı

\begin{tabular}{llll}
\hline Tablolar & Gruplar & Frekans(n) & Yüzde (\%) \\
& 25 Yaş Altı & 45 & 21,3 \\
& $26-30$ Yaş & 70 & 33,2 \\
Yaş & 31-35 Yaş & 49 & 23,2 \\
& $36-40$ Yaş & 32 & 15,2 \\
& 40 Yaş üstü & 15 & 7,1 \\
Medeni Durum & Toplam & 211 & 100,0 \\
& & & \\
& Evli & 75 & 35,5 \\
Suç Türü & Bekâr & 136 & 64,5 \\
& Toplam & 211 & 100,0 \\
& & & \\
& Cinsel Suçlar & 18 & 8,5 \\
& Uyuşturucu & 21 & 10,0 \\
& Hırsılık Yağma Dolandırıcılık & 88 & 41,7 \\
\hline
\end{tabular}




\begin{tabular}{llll}
\hline & Cinayet & 45 & 21,3 \\
& Yaralama & 23 & 10,9 \\
& Evrakta Sahtecilik ve Çete & 16 & 7,6 \\
Toplam & 211 & 100,0 \\
Bulunduğu Kurum & & \\
& Bilecik & & 34,6 \\
& Silivri & 73 & 37,0 \\
Uşak & 78 & 28,4 \\
Toplam & 60 & 100,0 \\
& Akdeniz Bölgesi & 211 & \\
& Ege Bölgesi & 7 & 3,3 \\
Marmara Bölgesi & 44 & 20,9 \\
& Karadeniz Bölgesi & 44 & 20,9 \\
& İç Anadolu Bölgesi & 25 & 9,0 \\
& Doğu Anadolu Bölgesi & 33 & 11,8 \\
Güneydoğu Anadolu Bölgesi & 39 & 15,6 \\
Toplam & 211 & 100,0 \\
\hline
\end{tabular}

Tablo 2'de görüldügü gibi öğrencilerin 45'i (\%21,3) 25 yaş altı, 70'i (\%33,2) 26-30 yaş, 49'u (\%23,2) 31-35 yaş, 32'si $(\% 15,2)$ 36-40 yaş, 15'i $(\% 7,1) 40$ yaş üstü olarak dağılımaktadır. Öğrenciler medeni durum değişkenine göre 75'i $(\% 35,5)$ evli, 136'sı $(\% 64,5)$ bekâr olarak dağılmaktadır. Öğrenciler suç türü değişkenine göre 18 'i $(\% 8,5)$ cinsel suçlar, 21 'i $(\% 10,0)$ uyuşturucu, 88'i $(\% 41,7)$ hırsızlık yağma dolandırıcılık, 45'i $(\% 21,3)$ cinayet, 23'ü $(\% 10,9)$ yaralama, 16 'sı $(\% 7,6)$ evrakta sahtecilik ve çete olarak dağılmaktadır. Öğrenciler bulunduğu kurum değişkenine göre 73'ü $(\% 34,6)$ Bilecik, 78'i $(\% 37,0)$ Silivri 7 No'lu 60'ı $(\% 28,4)$ Uşak ceza infaz kurumu olarak dağılmaktadır. Öğrenciler memleket değişkenine göre 7 'si $(\% 3,3)$ Akdeniz bölgesi, 44'ü $(\% 20,9)$ Ege bölgesi, 44'ü $(\% 20,9)$ Marmara Bölgesi, 19'u $(\% 9,0)$ Karadeniz Bölgesi, 25'i $(\% 11,8)$ iç Anadolu Bölgesi, 33'ü $(\% 15,6)$ Doğu Anadolu Bölgesi, 39'u $(\% 18,5)$ Güneydoğu Anadolu Bölgesi olarak dağılmaktadır.

\subsection{Verilerin Toplanması}

Araştırmanın nicel verileri, Kişisel Bilgi Formu ile Özdemir ve Akkaya (2014) tarafından geliştirilen Okumaya Yönelik Tutum Ölçeği (OYTÖ) kullanılarak nitel verileri ise odak grup görüşmesi ile elde edilmiştir.

Odak grup görüşmeleri, önceden belirlenmiş yönergeler çerçevesinde gerçekleştirilen, bu yöntemin mantığına uygun olarak, görüşülen kişilerin öznelliklerini ön planda tutan, katılımcıların söylemine ve bu söylemin toplumsal bağlamına dikkat edilmesi gereken nitel bir veri toplama tekniği olarak tanımlanabilir. Bu anlamda odak grup görüşmeleri, grupların, alt grupların, bilinçli, yarı bilinçli veya bilinçsiz olarak yaptıkları davranışlar ve psikolojik ve sosyo-kültürel özellikleri hakkında bilgi almayı, davranışlarının ardındaki nedenleri öğrenmeyi amaçlayan nitel bir yöntemdir. (Akşit, 1992).

Bireysel görüşmelerle elde edilemeyen birçok bilgi, grupça görüşmelerle sağlanabilir. Bunu sağlayan etmenler arasında, üyelerin birbirinden destek alarak acı gerçeklere daha kolay değinebilmeleri; her üyenin, baştan değişmez sandığı görüşlerinin, öteki üyelerce sunulan yeni bilgiler ışığında, kolayca değişebilmesi, yeni durumlar alabilmesi; görüşmeye, kaynak kişiler için olan güdüleyici etkisinin artması sonucu, daha fazla zaman ayırabilmesi önemli bir yer tutar" (Goldman, 1970:262'den akt. Karasar, 2007: 167). edilmiştir:

Araştırmanın nitel verilerinin elde edilmesi için aşağıdaki işlem basamakları takip 
$\checkmark$ Araştırma konusu Açık Öğretim Lisesi öğrencisi hükümlü ve tutukluların okuma tutumları olarak tespit edilmiştir. Öğrencilerin ceza infaz kurumlarında okuma tutumlarını etkileyen faktörler önem sırasına göre belirlenerek konunun sınırları çizilmiştir.

$\checkmark$ ikinci işlem basamağında araştırmaya katılacak kişiler, bu kişilerin özellikleri, görüşmede kullanılacak ana başlıklar ve sorulacak sorular belirlenerek, sorular hakkında ceza infaz kurumlarında çalışan öğretmenler ve okuma tutumu üzerinde akademik çalışmalar yapan akademisyenlerle görüş alışverişinde bulunulmuştur.

$\checkmark$ Üçüncü aşamada odak grup görüşmesinin yeri ve zamanı belirlenerek Silivri 7 No'lu ceza infaz kurumunda 8 Açık Öğretim Lisesi öğrencisi hükümlü ve tutuklu ile rehberlik saatinde kurum öğretmeni tarafından (araştırmacı) görüşme gerçekleştirilmiştir. Görüşme 90 dakika sürmüştür. Kurumlarda görüntü ve ses kaydı alınmasına müsaade edilmediği için görüşmeler not alma suretiyle kayıt altına alınmış aynı zamanda veri kaybı oluşmaması için yarı yapılandırılmış görüşme formunu doldurmaları da sağlanmıştır. Görüşmeler yapılırken Krueger'in (1998) soruların sırası hakkında belirttiği aşağıdaki sıra takip edilmiştir:

1. Açılış: Her katılımcı bir dakika gibi kısa bir sürede kendini tanıtır.

2. Tanıtma soruları: Bir, iki soru örneği verilir. Her soru için en fazla beş dakika verilir. Bu soruların amacı katılımcıları tartışılacak konuya ısındırmaktır.

3. Geçiş soruları: Bir, iki soru tartışılabilir; ancak verilen süre 7-8 dakikayı geçmemelidir. Bu sorular, tanıtma soruları ve anahtar sorular arasında köprü olabilir; fakat daha derinlemesine sorulardır. Bu sorulardan itibaren katılımcılar artık diğer katılımcılarla düşüncelerini paylaşırlar.

4. Anahtar sorular: İki, üç soru olabilir ve konuyu tartışacak kadar zaman tanınabilir. Bu süre 10-15 dakika olabilir. Bu sorular odak grubun temel sorularıdır. Araştırma sorularına odaklanılır, buraya kadar geçen süre toplam sürenin yarısı kadardır.

5. Araştırma soruları: Bir, iki adet olabilir; bu sorular için de 10-15 dakika verilebilir. Bu süre odak grup görüşmesinin uzunluğuna bağlıdır.

6. Kapanış sorusu: Genellikle son bir sorudur ve bu soru için 3-5 dakika verilebilir. Katılımcıların son cümlelerini sunmaları sağlanır.

7. Final sorusu: Katılımcılara kısaca değinilmeyen bir konu olup olmadığı sorulur.

$\checkmark$ Bir sonraki aşamada görüşme özetlenmiş, alınan notlar incelenmiş, görüşmeler analiz edilerek raporlaştırılmıştır. Raporlaştırma sırasında öğrencilerin isimleri kullanılmamış bunun yerine Ö1, Ö2, Ö3 şeklinde sıralı biçimde görüşmeye katılan sekiz öğrenci isimlendirilmiştir.

\section{4. Ölçeğin Geçerliliğine ilişkin Bulgular}

Araştırmada kullanılan ölçeğin çalışma grubunun yaşları ortaöğretim lise düzeyinde iken bizim araştırmamızda daha ileri yaş aralığında öğrenciler yer almaktadır. Bu nedenle ölçeğe ilişkin geçerlik ve güvenirlik çalışmaları tekrarlanmıştır.

Okuma Tutumu Ölçeği'nin yapı geçerliliğini ortaya koymak amacıyla açımlayıcı faktör analizine uygunluğunu anlamak için $\mathrm{KMO}$ ve Barlett testi yapılmıştır. KMO testi ölçüm sonucunun .60 ve daha üstü, Barlett küresellik testi sonucunun ise istatistiksel olarak anlamlı olması gerekir (Jeong, 2004). Yapılan Barlett küresellik testi sonucu anlamlı bulunmuş $(p=0.000<0.05)$, KMO testi sonucu $=0.871>0,60$ olarak tespit edilmiştir. Bu bulgular ışığında ölçeğe açımlayıcı faktör analizi yapılabileceği sonucuna varılmıştır. Faktör analizinde varimax döndürme yöntemi kullanılmıştır. Toplam açıklanan varyans \%51.017 olarak bulunmuş ve maddelerin 4 faktör altında toplandığı belirlenmiştir. Ölçeğe ait oluşan faktör yapısı aşağıda görülmektedir.

Tablo 2

Okuma Tutum Ölçeği Faktör Yapısı 


\begin{tabular}{|c|c|c|c|c|}
\hline \multirow[t]{6}{*}{ Boyut } & Madde & $\begin{array}{l}\text { Faktör } \\
\text { Yükü }\end{array}$ & $\begin{array}{l}\text { Açıklanan } \\
\text { Varyans }\end{array}$ & $\begin{array}{l}\text { Cronbach's } \\
\text { Alpha }\end{array}$ \\
\hline & S2 & 0,755 & & \\
\hline & S8 & 0,752 & & \\
\hline & S11 & 0,687 & & \\
\hline & S5 & 0,677 & & \\
\hline & S6 & 0,674 & & \\
\hline \multirow{10}{*}{$\begin{array}{l}\text { Yarar } \\
\text { (Özdeğer=8.700) }\end{array}$} & S7 & 0,651 & & \\
\hline & S4 & 0,594 & 19,129 & 0,888 \\
\hline & S3 & 0,577 & & \\
\hline & S10 & 0,551 & & \\
\hline & S9 & 0,546 & & \\
\hline & S12 & 0,515 & & \\
\hline & S1 & 0,506 & & \\
\hline & S24 & 0,720 & & \\
\hline & S25 & 0,711 & & \\
\hline & S22 & 0,652 & & \\
\hline \multirow{6}{*}{$\begin{array}{l}\text { Adanma } \\
\text { (Özdeğer=3.046) }\end{array}$} & S21 & 0,634 & 11,591 & 0,810 \\
\hline & S23 & 0,612 & & \\
\hline & S26 & 0,610 & & \\
\hline & S19 & 0,444 & & \\
\hline & S16 & 0,804 & & \\
\hline & S15 & 0,774 & & \\
\hline \multirow{6}{*}{$\begin{array}{l}\text { Alışkanlık } \\
\text { (Özdeğer=2.083) }\end{array}$} & S17 & 0,677 & & \\
\hline & S14 & 0,676 & 10,932 & 0,794 \\
\hline & S18 & 0,591 & & \\
\hline & S13 & 0,587 & & \\
\hline & S20 & 0,511 & & \\
\hline & S28 & 0,735 & & \\
\hline \multirow{4}{*}{$\begin{array}{l}\text { Gerçeği Aşma } \\
\text { (Özdeğer=1.476) }\end{array}$} & S27 & 0,718 & 9,365 & 0,848 \\
\hline & S29 & 0,666 & & \\
\hline & S30 & 0,438 & & \\
\hline & \multicolumn{4}{|c|}{ Toplam Varyans \%51.017 } \\
\hline
\end{tabular}

Ölçeği oluşturan faktörlerin güvenirlik katsayıları ve açıklanan varyans oranlarının yüksek olması ölçeğin güçlü bir faktör yapısına sahip olduğunu göstermiştir. Bu bulgularla okuma tutum ölçeğinin geçerli ve güvenilir bir araç olduğu anlaşılmıştır. Ölçeğin faktör yapısı incelendiğinde orijinal ölçek ile örtüşen bir yapı elde edilmiştir. Ölçekteki faktörlerin puanları hesaplanırken faktördeki maddelerin değerleri toplandıktan sonra madde sayısına bölünerek (aritmetik ortalama) faktör puanları elde edilmiştir.

\section{5. Ölçeğin Güvenilirliğine İlişkin Bulgular}

Ölçeğin genel güvenirliğine dair bulgular için Cronbach alfa katsayılara hesaplanmış ve ölçeğin tamamında .903; yarar alt boyutunda .888; adanma alt boyutunda .810; alışkanlık alt boyutunda .794 ve gerçeği aşma alt boyutunda .848 katsayılarına ulaşılmıştır. Büyüköztürk (2013:183) genel olarak .70 ve üzeri olan ölçeklerin güvenilir kabul edildiğini ifade etmektedir. Bu ifade doğrultusunda ölçeğin güvenilir olduğu söylenebilir. 


\subsection{Verilerin Analizi}

Araştırmada elde edilen veriler SPSS 22 paket programı kullanılarak analiz edilmiştir. Verilerin değerlendirilmesinde tanımlayıcı istatistiksel yöntemleri olarak sayı, yüzde, ortalama, standart sapma kullanılmıştır. Ölçek boyutlarının aldığı puanlar 1 ile 5 arasında değerlendirilmektedir. Bu aralık 4 puanlık genişliğe sahiptir. Bu genişlik beş eşit genişliğe ayrılarak 1.00- 1.79 arası çok düşük, $1.80-2.59$ arası düşük, 2.60- 3.39 arası orta, 3.40-4.19 arası yüksek, 4.20-5.00 arası çok yüksek kabul edilerek bulgular yorumlanmıştır (http://www.istatistikanaliz.com/faktor analizi.asp). Araştırma değişkenlerinin tanımlayıcı özelliklere göre normal dağılım gösterip göstermediği Kormogov Simirnov testi ile analiz edilmiştir. Değişkenlerinin tanımlayıcı özelliklere göre normal dağılım göstermediği saptanmış $(p<0,05)$, verilerin analizinde parametrik olmayan yöntemler kullanılmıştır. İki bağımsız grup arasında niceliksel sürekli verilerin karşılaştırılmasında Man Whitney-u testi, ikiden fazla bağımsız grup arasında niceliksel sürekli verilerin karşılaştırılmasında Kruskall Wallis testi kullanıımıştır. Kruskall Wallis testi sonrasında farklııkları belirlemek üzere tamamlayıcı olarak Man Whitney-u testi kullanılmıştır. Elde edilen bulgular \%95 güven aralığında, \%5 anlamlılık düzeyinde değerlendirilmiştir.

Araştırmanın nitel verilerinin analizi ise içerik analizi ile gerçekleştirilmiştir. "İçerik analizi insan davranışları üzerinde doğrudan olmayan yollarla çalışmaya imkân tanıyan bir tekniktir. İçerik analizi özellikle sosyal bilimlerde çoğunlukla kullanılan önemli bir tekniktir" (Büyüköztürk, 2013). AÖL öğrencisi hükümlü ve tutuklular ile yapılan odak grup görüşmesi neticesinde elde edilen veriler detaylı bir işleme tabi tutulup, kavram ve temalar analiz sonucu mantıklı bir şekilde tasniflenerek verilere açıklamalar getiren temalar belirlenmiştir.

\section{BULGULAR ve YORUMLAR}

\subsection{Araştırmanın Nitel Verilerine iliş̧kin Bulgular}

Araştırmanın nitel verilerine ilişkin bulguları, çalışmanın g-h-i-j-k-I alt problemleri doğrultusunda ele alınmış, bu alt problemler ekseninde kodlanarak analiz edilmiştir:

\subsubsection{Tutukluluk ve Okuma İlişkisi}

Araştırmanın öğrencilerin tutuklanma durumlarının okumaya yönelik tutumlarına nasıl bir etkide bulunduğunu tespit etmeyi amaçlayan alt problemi doğrultusunda öğrencilere görüşme sırasında ilk soru olarak "Ceza infaz kurumunda okuma imkânınız var mı? Varsa neler okuyorsunuz?" sorusu yöneltilmiştir. Görüşmeye katılan öğrencilerin tamamı kurumlarda okuma imkânı bulduklarını, çoğunlukla kitap ve gazete okuduklarını belirtmişlerdir. Ö5 bu soruya "Cezaevi çok kalabalık ve çok fazla boş zamanımız olduğu için azami derecede etkileşimden kaçmak için genelde zamanımı ranzamda geçiriyorum ve bu zamanı da en iyi kitap okuyarak geçirmek en etkili yöntem." şeklinde cevaplayarak kitap okumayı boş zamanlarını en iyi şekilde değerlendirmenin etkili bir yöntemi olarak gördüğünü ifade etmiştir. Ö8 ise bu soruyu "Ceza infaz kurumunda okuma imkânım var. Kitap, gazete, ders kitapları okuyorum. Okumaktan zevk alıyorum. Okuyarak kendimi geliştiriyorum. Gazete okuyorum ve böylece güncel haberleri takip ediyorum. Kendimi geliştireceğim, bilgi sahibi olacağım kitapları, gazete, roman tarzı kitapları okuyorum." şeklinde cevaplandırmıştır. Ö8, kitap okumanın boş zamanlarını değerlendirmenin yanı sıra bir başka boyutta yararı olan dış dünyadan haber alma aracı olma özelliğine değinmiştir. Kapalı bir ortamda barındırılan hükümlü ve tutuklular için okuma, bir nevi dış dünyaya açılan bir pencere olma niteliği taşımaktadır denilebilir.

Araştırmada aynı alt problem için öğrencilere "Tutuklanmadan önce mi çok okuyordunuz, tutuklandıktan sonra mı çok okumaya başladınız?" sorusu yöneltilmiştir. Öğrencilerin tamamı, tutuklanmaları sonrasında daha çok okumaya başladıklarını ifade 
etmişlerdir. Ö3 bu soruyu "Tutuklanmadan önce kitap okumuyordum. Tutuklandıktan sonra okumayı sevdiğimin farkına vardım. Özgürken kitap okumaya kimse teşvik etmedi. Etrafımda okuyan çok fazla kimse yoktu, oysa ceza infaz kurumlarında etrafımda hem okuyan insanlar var hem de okumaya teşvik eden öğretmenler ve zengin içerikli kütüphaneler var." şeklinde yanıtlayarak ceza infaz kurumlarında okumaya yönelik tutumunda bir değişiklik söz konusu olduğunu ifade ederek okumaya teşvik edilmesinin önemi üzerinde durmuştur. Ö1 ise bu soruyu "Tutuklanmadan önce az okurdum. Tutuklandıktan sonra okumaya vakit bulabiliyorum. Kurumlarda kütüphanenin olması ve kütüphanede çok çeşitli kitapların bulunması okuma ve öğrenme isteğimi artırıyor." şeklinde cevaplamıştır. Ö1 ve Ö5'in cevaplarının ortak noktası kurumlarda bulunan zengin içeriğe sahip kütüphanelerin okuma tutumu üzerinde olumlu bir katkısının bulunduğu noktasıdır. Yapılan görüşmeler neticesinde öğrencilerin tutuklanma durumlarının okumaya yönelik tutumlarına olumlu yönde bir etkide bulunduğu anlaşılmaktadır. Öğrencilerin boş zamanlarının daha fazla olması, kurumlarda kütüphanelerin ve öğrencileri okumaya teşvik eden öğretmenlerin bulunması durumu, okuma tutumlarının olumlu yönde olmasına katkıda bulunan faktörler olarak görülmektedir. "Hükümlü ve tutukluların memnuniyetini sağlamak, birçok şeyden yoksunluk yaşadıkları ortam sonucu onlarda gelişen olumsuz duygu durumunu azaltarak onlara okuma ile kütüphane kullanma sevgisini kazandıracaktır. Bu, daha ileri boyutlarda ele alındığında yalnız tahliye olacak kişiye değil, aynı zamanda suçu azaltması bakımından topluma da yarar sağlayacağına inanılan bir katkıdır" (Demir, 2011: 411-412).

\subsubsection{Ceza İnfaz Kurumu Eğitim Birimi Çalışmaları ve Okuma İlişkisi}

Araştırmanın "Ceza infaz kurumları eğitim birimlerinin sağladığı imkânlar okumaya yönelik tutumlarını nasıl etkilemektedir?" alt problemi doğrultusunda öğrencilere "Ceza infaz kurumları okumanız için gerekli kitap, gazete vs. temininde size yardımcı oluyor mu, nasıl?" sorusu yöneltilmiştir. Öğrencilerin tamamı bu soruya evet yanıtını vermişlerdir. Ö2 bu soruyu “ Yayınevlerine kurum yardımıyla faks çektirerek kitap isteyebiliyoruz. Ailelerimizden gelen hediye kitapları koliler halinde kurum idaresi bize teslim ediyor." şeklinde Ö6 ise "Cezaevinde okumayı engelleyen bir durum yok. Okumamı için her türlü ilgileniyorlar." şeklinde yanıtlamıştır. Bu cevaplardan da anlaşılacağı gibi ceza infaz kurumları eğitim birimleri hükümlü ve tutuklu öğrencilerin okuma tutumlarını yaptıkları hizmet sayesinde olumlu bir şekilde etkilemektedir. Öğrenciler tutuklu, hükümlü de olsalar faks yoluyla yayınevlerine ulaşabilmekte ve istedikleri kitabı satın almak suretiyle okuyabilmektedirler. Aynı şekilde hediye gelen kitaplara ulaşmalarında da herhangi bir sıkıntı bulunmamaktadır. Ceza infaz kurumlarında günlük gazetelerin tüm isteyenlere ulaştırılması durumu da okuma tutumunu olumlu yönde etkileyen bir etmen olarak görülebilir.

\subsubsection{AÖL Öğrenciliği ve Okuma Ilişkisi}

Çalışmanın "Hükümlü ve tutukluların AÖL öğrencisi olmaları okumaya yönelik tutumlarında bir değişiklik meydana getirmekte midir?" alt problemi doğrultusunda öğrencilere "AÖL öğrencisi olmanızın okumayı sevmenizde ya da sevmemenizde daha çok ya da daha az okumanızda nasıl bir etkisi oldu?" sorusu yöneltilmiştir. Bu soruyu öğrenciler genellikle öğrencilik durumlarının okumayı sevmelerinde olumlu bir etkisinin olduğunu belirterek cevaplamışlardır. Ö8 "Öğrenci olduğumuz için bilgi sahibi olmamız gerekiyor. Bunun için de ögretici kitaplar okuyoruz. Böylelikle okumanın gerekli bir aktivite olmasından hareketle okuma etkinliğimiz daha fazla zaman alıyor." şeklinde cevaplamıştır. Ö7 ise "Tabii ki öğrenci olmamızın okumayı sevmemizde çok büyük faydası oldu." diyerek düşüncelerini dile getirmiş̧ir. Ö3 ise konu hakkındaki düşüncelerini "AÖL bilgiye dayalı olan bir öğretim sistemi. Bilgi okuyarak öğrenilir. Böyle bir etkisi oldu." şeklinde ifade etmiştir. Bu yanıtlara dayalı olarak hükümlü ve tutukluların AÖL öğrencisi olmalarının okuma tutumlarını olumlu yönde etkilediği söylenebilir. 


\subsubsection{Tutuklu-Hükümlü Olmaya Bağlı Vakit ve Okuma İlişkisi}

Ceza infaz kurumu ortamında hükümlü ve tutukluların fazla vakte sahip olmaları okumayı sevmelerine, okumaya ihtiyaç hissetmelerine neden olmakta mıdır? Şeklinde belirlenen j alt problemi doğrultusunda hükümlü ve tutuklu AÖL öğrencilerine "Tutuklulukhükümlülük durumunuzun okumayı sevmeniz ya da sevmemenizde; daha az ya da daha çok okumanızda nasıl bir etkisi oldu?" sorusu yöneltilmiştir. Bu soruya AÖL öğrencilerinin tamamının verdiği cevap daha fazla vakitleri olduğu için ceza infaz kurumunda daha çok okudukları yönündedir. Ö2 bu soruyu "Tutuklanmadan önce gazete okuyordum. Tutuklandıktan sonra boş vaktim çok olduğundan daha çok okuyorum ve vaktim böylece güzel geçiyor." diyerek cevaplandırırken Ö6 "Büyürken ailemizde okuma adına yalnızca ders kitabının okunabileceğini öğrendik ve ders kitabı dışında kitapları okumaya yönlendirilmek bir yana engellendik. Çevremizde okuyan hiç kimse yoktu, yönlendiren olmadı. Tam tersine okuyanı öteleyen bir çevrem vardı. Bulunduğum çevreler olan Bahçelievler/Yayla; Büyükçekmece /Karagümrük; Esenler/ Otogaraltı; Şişli/Kuştepe; Beyoğlu/Tarlabaşı gibi çevrelerdi. Bu çevrelerde okuyana rastlamak mümkün değildi. Okuyan insanlar buralarda ötelenirdi. Burada çocuk, okuma yerine kavga etmeye yönlendiriliyordu. Okul yolunda çetelere rastları diye beslenme çantamıza taş koymamı yönünde telkinler geliyordu. Mahalle arası grup kavgaları oluyordu çünkü. Ama ceza infaz kurumunda bu durum tersine döndü. Okumaya eğitim birimi tarafından yönlendirildim ve zamanımın çoğunu okuyarak geçiriyorum. Okuma sevgimi artıran bir diğer faktör de okudukça rastladığım kitaplardan biri olan Halil CiBRAN'ın Nebî adlı eseri oldu. Bu kitap hayatı anlamama, kendimi tanımama, okumayı daha çok sevmeme neden oldu." diyerek ceza infaz kurumunda bulunması ve okuma tutumu arasındaki ilişkiye açıklık getirmiştir. Ö5 ise bu soruyu "Burada daha fazla okuyorum. Okuma sayesinde konuşma becerim de gelişiyor. Ayrıca dışarıya mektup yazarken okuduğum kitapta beğendiğim ilgili yerleri alıntılayarak kullanıyorum." şeklinde cevaplayarak okuma becerisinin diğer dil becerileri olan konuşma ve yazma becerisine olan katkısına işaret etmiştir. Bu ifadelerden yola çıkılarak AÖL öğrencilerinin kurumlarda okuma alışkanlığı kazanmaları, okumaya yönelik olumlu tutum geliştirmeleri, konuşma ve yazma dil becerilerinin gelişmesini de sağlamaktadır denilebilir.

\subsubsection{Ceza İnfaz Kurumu Kütüphaneleri}

Araştırmada bir diğer alt problem olarak belirlenen "Ceza infaz kurumu kütüphaneleri okumaya yönelik tutumlarını nasıl etkilemektedir?" alt problemi doğrultusunda görüşmede öğrencilere "Ceza infaz kurumları kütüphaneleri okumayı sevmenize ya da sevmemenize nasıl bir etkide bulunuyor?" sorusu yöneltilmiştir. Öğrencilerin tamamı bu soruyu kurum kütüphanelerinin okuma tutumlarını olumlu yönde etkilediğini söyleyerek cevaplamışlardır. Ö7 "Kütüphane okumama yardımcı oluyor ve istediğim bütün kitaplara ulaşabiliyorum." yanıtını; Ö8 ise "Kütüphaneler okumayı sevmeme yardımcı oluyor. Kütüphane olmasa kitap temin etmek ya da okumakta zorlanırdım. Kütüphane iyi ki var." yanıtını vermiştir. Ö6 ise "Kütüphanenin olumlu katkısı var ancak bir daha güncellenip yeni kitaplar gelirse bu katkının artacağını düşünüyorum." diyerek kurum kütüphanelerinin güncel yayınları takip etmesi, yayın çeşidini artırması gibi gereksinimlerine işaret etmiştir. Ö1 ise "Kurum kütüphanelerine sivil toplum kuruluşları, yayınevleri bağışta bulunurlarsa kitap çeşidi artar. Kitap yazarları kurumlara gelip sohbet yapar, kitap imzalarlarsa hükümlü ve tutukluların okumaları artabilir, daha çok kitaba ilgi duyabilirler." diyerek sosyal sorumluluk alanına parmak basmıştır. Ceza infaz kurumları kütüphaneleri Adalet Bakanlığı tarafından yasaklanmamış olan kitapları bağış olarak kabul etmektedir. Eğitim faaliyetleri içerisinde Ö1'in de belirttiği gibi yazar okur buluşmalarının kurumlarda sağlanması, hükümlü ve tutukluların okumaya yönelik olumlu tutum geliştirmelerinde ve böylelikle okuma alışkanlığı geliştirmelerinde yararlı bir faaliyet olarak görülebilir. 


\subsubsection{Mahpusluk-Okuma-Duygu Illişkisi}

Araştırmanın nitel son alt problemi olarak "okumanın öğrencilerin hislerine olan etkisi nasıldır? Problemi doğrultusunda öğrencilere "ceza infaz kurumlarında okuma tutumunuzu olumlu olumsuz etkileyen durumlar nelerdir? Okuyunca ya da okumayınca neler hissediyorsunuz?" soruları yöneltilmiştir. Öğrenciler genellikle eğitim biriminin, kütüphanenin destekleri doğrultusunda okumaya yönelik olumlu tutum geliştirdiklerini belirtmişlerdir. Olumlu tutumlarının yanı sıra kendilerini, okumalarını etkileyen olumsuz durumlara da değinmişlerdir. Ö5 "Cezaevindeki en büyük sorun koğuşun ve odaların çok dolu olması. Sosyal olarak anlaşamadığınız biri ile aynı yerde bulunmak sorun. Okuduğum sayfayı geri gelip beş kez okumak zorunda kalıyorum. Çünkü kalabalık olduğundan dikkatim çabuk dağılıyor ve hiçbir şey anlayamıyorum." diyerek okumasını olumsuz etkileyen bir durumu belirtmiştir. Ö6 "Kitap okurken vaktin nasıl geçtiğini anlayamıyorum. Kitap okumak beni koğuşta olabilecek kişisel olaylardan, kavgalardan da uzak tutuyor. Bu yönüyle kitap okumak çok faydalı ve kendimi iyi hissettiren bir alışkanlık." diyerek kitap okumanın kalabalık koğuş ortamından yaşama mecburiyetinde olaylardan uzak tutma yönüyle koruyucu bir yönü de olduğuna vurgu yapmıştır. Ö7 ise "Burada okumayı etkileyen olumsuz bir durum yok çünkü okumamı için bütün imkânlar tanınıyor." diyerek kurumların okumayı desteklediğini ifade etmiştir. Ö1 ise kitap okumanın hislerine olan etkisini "Kitap okurken koğuşun günlük mevzusundan, tartışmalarından uzak kalıyorum. Mahpus olma hâlimi unutuyorum. Kendimi film izler gibi başka mekânda hissediyorum. Sürükleyici eserleri gerçeklikten kaçmak için daha çok tercih ediyorum." şeklinde ifade etmiştir. Ö3 ise okuyarak sıkıntısının azaldığına değinerek "Mizah dergilerini okuyarak mutlu oluyorum. Gülme ihtiyacını karşılaması, sıkıntının azaltılması için birebir. Burada ortam zaten mutsuz. Bunu değiştirmenin tek yolu sıkıntıyı azaltan dergi ve kitapları okumaktır." demiştir. Araştırmanın bu alt problemi doğrultusunda öğrencilere ayrıca okumaya yönelik olumlu hislerinizi artırmada kurum idaresi ve eğitim birimleri neler yapmalılar? sorusu sorulmuştur. Ö1 bu soruya "Kurum kütüphanesinde bulunan kitapları gösteren listenin yarısı dinî kitaplardan oluşuyor. Çünkü bu kitapları yayınevleri bağış gönderiyorlar. Oysa diğer kitapları basan yayınevleri yeteri kadar kitap bağışında bulunmuyorlar. Bu yayınevlerinin de bağışta bulunması için girişimlerde bulunulmalıdır." derken Ö4 "Kütüphane kitap listeleri koğuşumuzda var ama bunların sadece isimlerini görüyoruz ve içeriklerini bilmiyoruz. İsimden yola çıkarak haftada bir olan kitap istek hakkımızı kullanıyoruz. İ̧̧erik hoşumuza gitmezse o haftaki kitap istek hakkımız boşa gitmiş oluyor. Oysa bizlere kütüphaneye çıkarak kitap seçme hakkı verilse çok daha isabetli kitapları, istediğimiz, hoşumuza giden kitapları okuyabiliriz." diyerek okuma tutumunu olumlu etkileme yolunda kurum idare ve eğitim birimleri tarafından yapılabileceklere parmak basmıştır denilebilir. Ö2 ise kitap okuma yönünde kendisini olumlu etkileyen bir başka hisse değinmiş "Tutuklandıktan sonra dinî kitapları daha fazla yöneldim. Kurtuluşun doğru dinî bilgi olduğunu düşünüyorum. Manevi desteğe duyduğum gereksinimi dinî kitapları okuyarak gideriyorum." diyerek kitap okuma yoluyla manevi boşluğunu kapatmaya çalıştığını ifade etmiştir.

\subsection{Araştırmanın Nicel Verilerine iliş̧kin Bulgular}

Araştırmanın ilk sorusuna (öğrencilerin okumaya yönelik tutumları genel olarak ne düzeydedir? ) ilişkin bulgular Tablo 3'te verilmiştir. 
Tablo 3

Öğrencilerin Okuma Tutum Düzeyleri

\begin{tabular}{llllll}
\hline & N & Ort & Ss & Min. & Max. \\
\hline Yarar & 211 & 4,329 & 0,631 & 2,000 & 5,000 \\
Adanma & 211 & 3,753 & 0,795 & 1,000 & 5,000 \\
Alışkanlık & 211 & 3,756 & 0,741 & 1,290 & 5,000 \\
Gerçeği Aşma & 211 & 4,238 & 0,840 & 1,000 & 5,000 \\
Okuma Tutum Genel & 211 & 4,049 & 0,536 & 2,130 & 5,000 \\
\hline
\end{tabular}

Araştırmaya katılan öğrencilerin "yarar" düzeyi çok yüksek $(4,329 \pm 0,631)$; "adanma" düzeyi yüksek $(3,753 \pm 0,795)$; "alışkanlık" düzeyi yüksek $(3,756 \pm 0,741)$; "gerçeği aşma" düzeyi çok yüksek $(4,238 \pm 0,840)$; “okuma tutum genel” düzeyi yüksek $(4,049 \pm 0,536)$; olarak saptanmıştır.

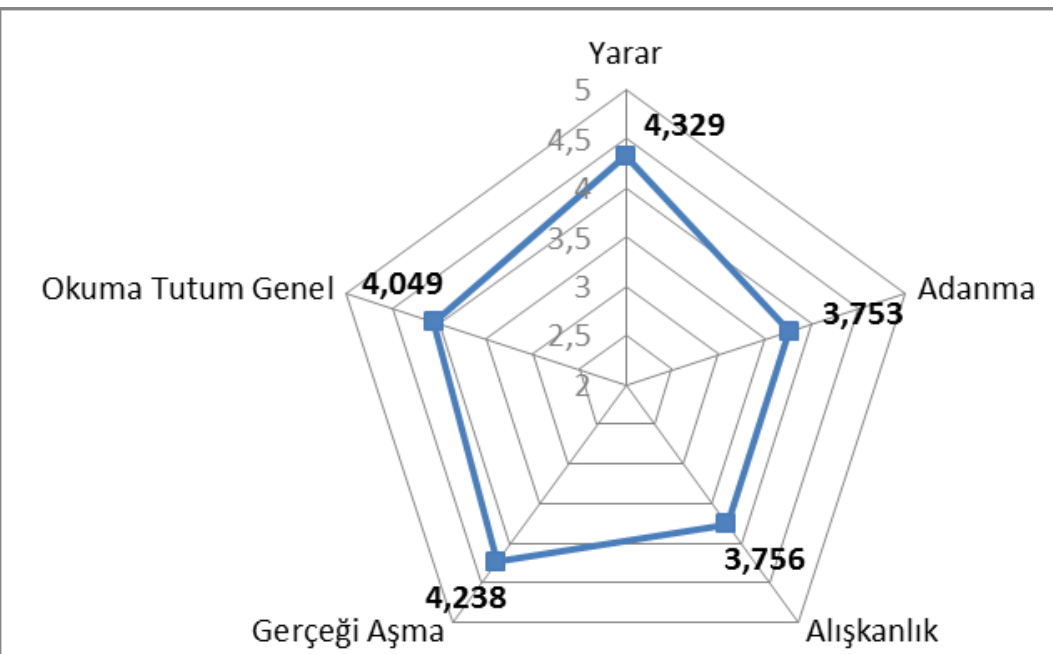

Şekil 1. Öğrencilerin okuma tutum düzeylerine ilişkin diyagram

Tablo 4

Öğrencilerin Okuma Tutum Düzeylerinin Tanımlayıcı Özelliklere Göre Farklılaşması

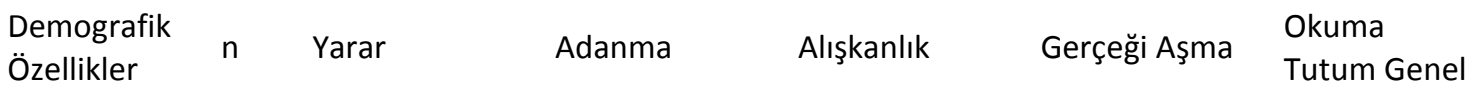

\begin{tabular}{|c|c|c|c|c|c|c|}
\hline Yaş & & $\begin{array}{l}\text { Ort. } \\
\text { Sıra(Med) }\end{array}$ & $\begin{array}{l}\text { Ort. } \\
\text { Sira(Med) }\end{array}$ & $\begin{array}{l}\text { Ort. } \\
\text { Sira(Med) }\end{array}$ & $\begin{array}{l}\text { Ort. } \\
\text { Sira(Med) }\end{array}$ & $\begin{array}{l}\text { Ort. } \\
\text { Sira(Med) }\end{array}$ \\
\hline 5 yaş al & 45 & $\begin{array}{l}103,070(4,50 \\
0)\end{array}$ & $\begin{array}{l}105,770(3,71 \\
4)\end{array}$ & $\begin{array}{l}105,180(3,85 \\
7)\end{array}$ & $\begin{array}{l}104,990(4,50 \\
0)\end{array}$ & $\begin{array}{l}105,270(4,10 \\
0)\end{array}$ \\
\hline
\end{tabular}




\begin{tabular}{|c|c|c|c|c|c|c|}
\hline $26-30$ yaş & 70 & $99,360(4,375)$ & $97,520(3,714)$ & $\begin{array}{l}106,350(3,85 \\
7)\end{array}$ & $\begin{array}{l}111,600(4,50 \\
0)\end{array}$ & $\begin{array}{l}100,510(4,00 \\
0)\end{array}$ \\
\hline 31-35 yaş & 49 & $\begin{array}{l}130,400(4,75 \\
0)\end{array}$ & $\begin{array}{l}115,920(3,85 \\
7)\end{array}$ & $\begin{array}{l}105,120(3,85 \\
7)\end{array}$ & $\begin{array}{l}109,340(4,50 \\
0)\end{array}$ & $\begin{array}{l}122,640(4,30 \\
0)\end{array}$ \\
\hline 36-40 yaş & 32 & $92,300(4,208)$ & $\begin{array}{l}109,940(4,00 \\
0)\end{array}$ & $\begin{array}{l}101,840(3,85 \\
7)\end{array}$ & $99,950(4,000)$ & $97,280(4,067)$ \\
\hline 40 yaş üstü & 15 & $95,300(4,083)$ & $\begin{array}{l}105,470(3,85 \\
7)\end{array}$ & $\begin{array}{l}118,570(4,14 \\
3)\end{array}$ & $84,900(4,250)$ & $98,030(4,100)$ \\
\hline$\chi^{2}{ }_{k W}=$ & & 10,947 & 2,788 & 0,808 & 3,039 & 5,124 \\
\hline$p=$ & & 0,027 & 0,594 & 0,937 & 0,551 & 0,275 \\
\hline $\begin{array}{l}\text { Ileri Test } \\
(\mathrm{MWU})=\end{array}$ & & $\begin{array}{l}3>1,3>2,3>4 \\
(p<0.05)\end{array}$ & & & & \\
\hline
\end{tabular}

\begin{tabular}{|c|c|c|c|c|c|c|}
\hline $\begin{array}{l}\text { Medeni } \\
\text { Durum }\end{array}$ & & $\begin{array}{l}\text { Ort. } \\
\text { Sira(Med) }\end{array}$ & Ort \pm SS & $\begin{array}{l}\text { Ort. } \\
\text { Sira(Med) }\end{array}$ & $\begin{array}{l}\text { Ort. } \\
\text { Sira(Med) }\end{array}$ & $\begin{array}{l}\text { Ort. } \\
\text { Sira(Med) }\end{array}$ \\
\hline Evli & 75 & $\begin{array}{l}102,630(4,33 \\
3)\end{array}$ & $3,720 \pm 0,785$ & $\begin{array}{l}116,160(4,00 \\
0)\end{array}$ & $96,620(4,250)$ & $\begin{array}{l}102,430(4,06 \\
7)\end{array}$ \\
\hline Bekar & $\begin{array}{l}13 \\
6\end{array}$ & $\begin{array}{l}107,860(4,50 \\
0)\end{array}$ & $3,771 \pm 0,803$ & $\begin{array}{l}100,400(3,85 \\
7)\end{array}$ & $\begin{array}{l}111,170(4,50 \\
0)\end{array}$ & $\begin{array}{l}107,970(4,13 \\
3)\end{array}$ \\
\hline $\mathrm{t}=$ & & & $-0,445$ & & & \\
\hline $\mathrm{MWU} / \mathrm{Z}=$ & & $\begin{array}{l}4847,000 /- \\
0,599\end{array}$ & & $\begin{array}{l}4338,000 /- \\
1,799\end{array}$ & $\begin{array}{l}4396,500 /- \\
1,711\end{array}$ & $\begin{array}{l}4832,000 /- \\
0,632\end{array}$ \\
\hline$p=$ & & 0,549 & 0,657 & 0,072 & 0,087 & 0,528 \\
\hline Suç Türü & & $\begin{array}{l}\text { Ort. } \\
\text { Sira(Med) }\end{array}$ & Ort \pm SS & $\begin{array}{l}\text { Ort. } \\
\text { Sira(Med) }\end{array}$ & $\begin{array}{l}\text { Ort. } \\
\text { Sira(Med) }\end{array}$ & $\begin{array}{l}\text { Ort. } \\
\text { Sira(Med) }\end{array}$ \\
\hline $\begin{array}{l}\text { Cinsel } \\
\text { suçlar }\end{array}$ & 18 & $\begin{array}{l}116,390(4,58 \\
3)\end{array}$ & $3,865 \pm 0,789$ & $\begin{array}{l}137,670(4,21 \\
4)\end{array}$ & $\begin{array}{l}105,220(4,37 \\
5)\end{array}$ & $\begin{array}{l}125,830(4,30 \\
0)\end{array}$ \\
\hline Uyuşturucu & 21 & $\begin{array}{l}109,070(4,66 \\
7)\end{array}$ & $3,714 \pm 0,798$ & $\begin{array}{l}106,400(3,85 \\
7)\end{array}$ & $96,260(4,250)$ & $\begin{array}{l}104,710(4,06 \\
7)\end{array}$ \\
\hline $\begin{array}{l}\text { Hırsızlık } \\
\text { yağma } \\
\text { Dolandırıcılı } \\
\text { k }\end{array}$ & 88 & $\begin{array}{l}104,740(4,33 \\
3)\end{array}$ & $3,708 \pm 0,777$ & $\begin{array}{l}105,090(3,85 \\
7)\end{array}$ & $\begin{array}{l}106,450(4,37 \\
5)\end{array}$ & $\begin{array}{l}104,110(4,05 \\
0)\end{array}$ \\
\hline Cinayet & 45 & $\begin{array}{l}112,360(4,50 \\
0)\end{array}$ & $3,905 \pm 0,783$ & $\begin{array}{l}104,320(3,71 \\
4)\end{array}$ & $\begin{array}{l}119,910(5,00 \\
0)\end{array}$ & $\begin{array}{l}116,320(4,13 \\
3)\end{array}$ \\
\hline
\end{tabular}


Hatice ALTUNKAYA

\begin{tabular}{|c|c|c|c|c|c|c|}
\hline Yaralama & 23 & $91,260(4,083)$ & $3,596 \pm 0,683$ & $91,150(3,857)$ & $87,570(4,000)$ & $85,300(4,000)$ \\
\hline $\begin{array}{l}\text { Evrakta } \\
\text { sahtecilik } \\
\text { ve çete }\end{array}$ & 16 & $\begin{array}{l}100,500(4,50 \\
0)\end{array}$ & $3,723 \pm 1,087$ & $\begin{array}{l}100,910(3,85 \\
7)\end{array}$ & $\begin{array}{l}104,530(4,12 \\
5)\end{array}$ & $96,500(3,983)$ \\
\hline$\chi^{2} k W=$ & & 2,598 & & 6,398 & 5,310 & 6,314 \\
\hline $\mathrm{F}=$ & & & 0,644 & & & \\
\hline$p=$ & & 0,762 & 0,667 & 0,269 & 0,379 & 0,277 \\
\hline
\end{tabular}

\begin{tabular}{|c|c|c|c|c|c|c|}
\hline $\begin{array}{l}\text { Bulunduğu } \\
\text { Kurum }\end{array}$ & & $\begin{array}{l}\text { Ort. } \\
\text { Sira(Med) }\end{array}$ & $\begin{array}{l}\text { Ort. } \\
\text { Sira(Med) }\end{array}$ & $\begin{array}{l}\text { Ort. } \\
\text { Sira(Med) }\end{array}$ & $\begin{array}{l}\text { Ort. } \\
\text { Sira(Med) }\end{array}$ & $\begin{array}{l}\text { Ort. } \\
\text { Sira(Med) }\end{array}$ \\
\hline Bilecik & 73 & $96,550(4,333)$ & $\begin{array}{l}102,300(3,71 \\
4)\end{array}$ & $\begin{array}{l}\text { 114,390(3,85 } \\
7)\end{array}$ & $96,690(4,250)$ & $\begin{array}{l}\text { 101,180(4,06 } \\
7)\end{array}$ \\
\hline Silivri & 78 & $98,870(4,250)$ & $93,320(3,500)$ & $99,420(3,857)$ & $\begin{array}{l}102,390(4,50 \\
0)\end{array}$ & $95,270(4,000)$ \\
\hline Uşak & 60 & $\begin{array}{l}126,770(4,66 \\
7)\end{array}$ & $\begin{array}{l}\text { 126,980(4,14 } \\
3)\end{array}$ & $\begin{array}{l}104,340(3,85 \\
7)\end{array}$ & $\begin{array}{l}122,020(5,00 \\
0)\end{array}$ & $\begin{array}{l}125,820(4,26 \\
7)\end{array}$ \\
\hline$\chi^{2} k W=$ & & 9,861 & 10,759 & 2,339 & 6,497 & 9,192 \\
\hline$p=$ & & 0,007 & 0,005 & 0,311 & 0,039 & 0,010 \\
\hline $\begin{array}{l}\text { Ileri Test } \\
(\mathrm{MWU})=\end{array}$ & & $\begin{array}{ll}3>1, & 3>2 \\
(p<0.05) & \end{array}$ & $\begin{array}{ll}3>1, & 3>2 \\
(p<0.05) & \end{array}$ & & $3>1(p<0.05)$ & $\begin{array}{ll}3>1, & 3>2 \\
(p<0.05) & \end{array}$ \\
\hline Memleket & & $\begin{array}{l}\text { Ort. } \\
\text { Sıra(Med) }\end{array}$ & $\begin{array}{l}\text { Ort. } \\
\text { Sira(Med) }\end{array}$ & $\begin{array}{l}\text { Ort. } \\
\text { Sira(Med) }\end{array}$ & $\begin{array}{l}\text { Ort. } \\
\text { Sira(Med) }\end{array}$ & $\begin{array}{l}\text { Ort. } \\
\text { Sira(Med) }\end{array}$ \\
\hline $\begin{array}{l}\text { Akdeniz } \\
\text { Bölgesi }\end{array}$ & 7 & $\begin{array}{l}101,500(4,33 \\
3)\end{array}$ & $\begin{array}{l}142,360(4,14 \\
3)\end{array}$ & $\begin{array}{l}139,210(4,28 \\
6)\end{array}$ & $\begin{array}{l}106,640(4,25 \\
0)\end{array}$ & $\begin{array}{l}123,860(4,16 \\
7)\end{array}$ \\
\hline Ege Bölgesi & 44 & $\begin{array}{l}121,900(4,58 \\
3)\end{array}$ & $\begin{array}{l}122,780(4,14 \\
3)\end{array}$ & $85,890(3,714)$ & $\begin{array}{l}116,350(5,00 \\
0)\end{array}$ & $\begin{array}{l}115,770(4,23 \\
3)\end{array}$ \\
\hline $\begin{array}{l}\text { Marmara } \\
\text { Bölgesi }\end{array}$ & 44 & $\begin{array}{l}101,000(4,33 \\
3)\end{array}$ & $86,680(3,429)$ & $\begin{array}{l}107,320(3,85 \\
7)\end{array}$ & $\begin{array}{l}103,590(4,50 \\
0)\end{array}$ & $95,270(4,000)$ \\
\hline $\begin{array}{l}\text { Karadeniz } \\
\text { Bölgesi }\end{array}$ & 19 & $\begin{array}{l}104,420(4,16 \\
7)\end{array}$ & $86,630(3,286)$ & $\begin{array}{l}103,550(3,85 \\
7)\end{array}$ & $92,180(4,000)$ & $98,450(4,000)$ \\
\hline $\begin{array}{l}\text { İç Anadolu } \\
\text { Bölgesi }\end{array}$ & 25 & $96,220(4,500)$ & $99,760(3,857)$ & $\begin{array}{l}123,560(4,14 \\
3)\end{array}$ & $\begin{array}{l}105,960(4,25 \\
0)\end{array}$ & $\begin{array}{l}105,820(4,13 \\
3)\end{array}$ \\
\hline $\begin{array}{l}\text { Doğu } \\
\text { Anadolu } \\
\text { Bölgesi }\end{array}$ & 33 & $96,700(4,250)$ & $\begin{array}{l}100,880(3,71 \\
4)\end{array}$ & $\begin{array}{l}\text { 111,610(3,85 } \\
7)\end{array}$ & $95,790(4,250)$ & $99,260(4,000)$ \\
\hline
\end{tabular}




\begin{tabular}{|c|c|c|c|c|c|c|}
\hline $\begin{array}{l}\text { Güneydoğu } \\
\text { Anadolu } \\
\text { Bölgesi }\end{array}$ & 39 & $\begin{array}{l}109,420(4,58 \\
3)\end{array}$ & $\begin{array}{l}120,100(3,85 \\
7)\end{array}$ & $\begin{array}{l}106,440(3,85 \\
7)\end{array}$ & $\begin{array}{l}112,320(4,50 \\
0)\end{array}$ & $\begin{array}{l}113,370(4,13 \\
3)\end{array}$ \\
\hline$\chi^{2} k W=$ & & 4,913 & 14,754 & 9,290 & 3,887 & 4,350 \\
\hline$p=$ & & 0,555 & 0,022 & 0,158 & 0,692 & 0,629 \\
\hline $\begin{array}{l}\text { Illeri Test } \\
(\mathrm{MWU})=\end{array}$ & & & $\begin{array}{l}1>3,1>4,2>3 \\
2>4,7>3,7>4 \\
(p<0.05)\end{array}$ & & & \\
\hline
\end{tabular}

Araştırmanın ikinci alt problemine (öğrencilerin okumaya yönelik tutumları yaş değişkenine göre farklılık göstermekte midir?) ilişkin bulgular, Tablo 4'te verilmiştir. Araştırmaya katılan öğrencilerin yarar puanları ortalamalarının yaş değişkeni açısından anlamlı bir farklılık gösterip göstermediğini belirlemek amacıyla yapılan Kruskal Wallis H-Testi sonuçlarına göre; grup ortalamaları arasındaki fark anlamlı bulunmuştur $\left(\chi^{2}{ }_{\mathrm{kW}}=10,947\right.$; $\mathrm{p}=0.027<0.05)$. Farklılığın hangi gruptan kaynaklandığını belirlemek üzere Mann Whitney $U$ testi uygulanmıştır. Buna göre; 31-35 yaş olanların yarar puanları $(4,565 \pm 0,523), 25$ yaş altı olanların yarar puanlarından $(4,298 \pm 0,672)$ yüksek bulunmuştur. 31-35 yaş olanların yarar

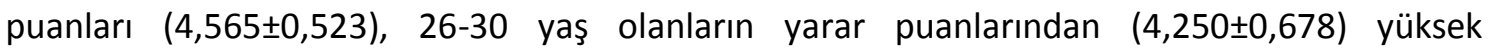
bulunmuştur. 31-35 yaş olanların yarar puanları $(4,565 \pm 0,523), 36-40$ yaş olanların yarar puanlarından $(4,214 \pm 0,590)$ yüksek bulunmuştur.

Araştırmaya katılan öğrencilerin adanma, alışkanlık, gerçeği aşma, okuma tutum genel puanları ortalamalarının yaş değişkeni açısından anlamlı bir farklılık gösterip göstermediğini belirlemek amacıyla yapılan test sonuçlarına göre grup ortalamaları arasındaki fark anlamlı bulunmamıştır( $>0.05)$.

Araştırmanın üçüncü alt problemine (Öğrencilerin okumaya yönelik tutumları suç türü değişkenine göre farklılık göstermekte midir?) ilişkin bilgiler Tablo 4'te yer almaktadır. Araştırmaya katılan öğrencilerin yarar, adanma, alışkanlık, gerçeği aşma, okuma tutum genel puanları ortalamalarının suç türü değişkeni açısından anlamlı bir farklılık gösterip göstermediğini belirlemek amacıyla yapılan test sonuçlarına göre grup ortalamaları arasındaki fark anlamlı bulunmamıştır( $p>0.05)$.

Araştırmanın dördüncü alt problemine (Öğrencilerin okumaya yönelik tutumları nereli olduklarına göre farklılık göstermekte midir?) ilişkin veriler Tablo 4'te görülmektedir. Araştırmaya katılan öğrencilerin adanma puanları ortalamalarının memleket değişkeni açısından anlamlı bir farklılık gösterip göstermediğini belirlemek amacıyla yapılan Kruskal Wallis H-Testi sonuçlarına göre; grup ortalamaları arasındaki fark anlamlı bulunmuştur $\left(\chi^{2}{ }_{\mathrm{KW}}=14,754 ; p=0.022<0.05\right)$. Farklılığın hangi gruptan kaynaklandığını belirlemek üzere Mann Whitney $U$ testi uygulanmıştır. Buna göre; Memleketi Akdeniz Bölgesi olanların adanma puanları $(4,225 \pm 0,546)$, memleketi Marmara Bölgesi olanların adanma puanlarından $(3,539 \pm 0,755)$ yüksek bulunmuştur. Memleketi Akdeniz Bölgesi olanların adanma puanları $(4,225 \pm 0,546)$, memleketi Karadeniz Bölgesi olanların adanma puanlarından $(3,504 \pm 0,828)$ yüksek bulunmuştur. Memleketi Ege Bölgesi olanların adanma puanları $(3,968 \pm 0,671)$, memleketi Marmara Bölgesi olanların adanma puanlarından $(3,539 \pm 0,755)$ yüksek bulunmuştur. Memleketi Ege Bölgesi olanların adanma puanları $(3,968 \pm 0,671)$, memleketi Karadeniz Bölgesi olanların adanma puanlarından $(3,504 \pm 0,828)$ yüksek bulunmuştur. 
Memleketi Güneydoğu Anadolu bölgesi olanların adanma puanları $(3,960 \pm 0,687)$, memleketi Marmara Bölgesi olanların adanma puanlarından $(3,539 \pm 0,755)$ yüksek bulunmuştur. Memleketi Güneydoğu Anadolu bölgesi olanların adanma puanları $(3,960 \pm 0,687)$, memleketi Karadeniz Bölgesi olanların adanma puanlarından $(3,504 \pm 0,828)$ yüksek bulunmuştur.

Araştırmaya katılan öğrencilerin yarar, alışkanlık, gerçeği aşma, okuma tutum genel puanları ortalamalarının memleket değişkeni açısından anlamlı bir farklılık gösterip göstermediğini belirlemek amacıyla yapılan test sonuçlarına göre grup ortalamaları arasındaki fark anlamlı bulunmamıştır ( $p>0.05)$.

Araştırmanın beşinci alt problemine (Öğrencilerin okumaya yönelik tutumları medeni durum değişkenine göre farklılık göstermekte midir?) ilişkin veriler Tablo 4'te verilmiştir. Araştırmaya katılan öğrencilerin yarar, adanma, alışkanlık, gerçeği aşma, okuma tutum genel puanları ortalamalarının medeni durum değişkeni açısından anlamlı bir farklılık gösterip göstermediğini belirlemek amacıyla yapılan test sonuçlarına göre grup ortalamaları arasındaki fark anlamlı bulunmamıştır ( $p>0.05)$.

Araştırmanın altıncı alt problemine (Öğrencilerin okumaya yönelik tutumları bulundukları ceza infaz kurumuna göre farklılık göstermekte midir?) ilişkin veriler tablo 4'te sunulmuştur.

Araştırmaya katılan öğrencilerin yarar puanları ortalamalarının bulunduğu kurum değişkeni açısından anlamlı bir farklılık gösterip göstermediğini belirlemek amacıyla yapılan Kruskal Wallis $\mathrm{H}$-Testi sonuçlarına göre; grup ortalamaları arasındaki fark anlamlı bulunmuştur $\left(\chi^{2}{ }_{K W}=9,861 ; p=0.007<0.05\right)$. Farklılı̆ın hangi gruptan kaynaklandığını belirlemek üzere Mann Whitney $U$ testi uygulanmıştır. Buna göre; bulunduğu kurum Uşak olanların yarar puanları $(4,544 \pm 0,491)$, bulunduğu kurum Bilecik olanların yarar puanlarından $(4,272 \pm 0,572)$ yüksek bulunmuştur. Bulunduğu kurum Uşak olanların yarar puanları $(4,544 \pm 0,491)$, bulunduğu kurum Silivri olanların yarar puanlarından $(4,217 \pm 0,736)$ yüksek bulunmuştur.

Araştırmaya katılan öğrencilerin adanma puanları ortalamalarının bulunduğu kurum değişkeni açısından anlamlı bir farklılık gösterip göstermediğini belirlemek amacıyla yapılan Kruskal Wallis $\mathrm{H}$-Testi sonuçlarına göre; grup ortalamaları arasındaki fark anlamlı bulunmuştur $\left(\chi^{2}{ }_{K W}=10,759 ; p=0.005<0.05\right)$. Farklıığın hangi gruptan kaynaklandığını belirlemek üzere Mann Whitney $U$ testi uygulanmıştır. Buna göre; bulunduğu kurum Uşak olanların adanma puanları $(4,017 \pm 0,719)$, bulunduğu kurum Bilecik olanların adanma puanlarından $(3,742 \pm 0,612)$ yüksek bulunmuştur. Bulunduğu kurum Uşak olanların adanma puanları $(4,017 \pm 0,719)$, bulunduğu kurum Silivri olanların adanma puanlarından $(3,560 \pm 0,942)$ yüksek bulunmuştur.

Araştırmaya katılan öğrencilerin gerçeği aşma puanları ortalamalarının bulunduğu kurum değişkeni açısından anlamlı bir farklııı gösterip göstermediğini belirlemek amacıyla yapılan Kruskal Wallis H-Testi sonuçlarına göre; grup ortalamaları arasındaki fark anlamlı bulunmuştur $\left(\chi^{2}{ }_{k W}=6,497 ; p=0.039<0.05\right)$. Farklılı̆ın hangi gruptan kaynaklandığını belirlemek üzere Mann Whitney $U$ testi uygulanmıştır. Buna göre; bulunduğu kurum Uşak olanların gerçeği aşma puanları $(4,404 \pm 0,878)$, bulunduğu kurum Bilecik olanların gerçeği aşma puanlarından $(4,216 \pm 0,593)$ yüksek bulunmuştur.

Araştırmaya katılan öğrencilerin okuma tutum genel puanları ortalamalarının bulunduğu kurum değişkeni açısından anlamlı bir farklııı gösterip göstermediğini belirlemek amacıyla yapılan Kruskal Wallis $\mathrm{H}$-Testi sonuçlarına göre; grup ortalamaları arasındaki fark anlamlı bulunmuştur $\left(\chi^{2}{ }_{\mathrm{KW}}=9,192 ; p=0.01<0.05\right)$. Farklılığın hangi gruptan kaynaklandığını belirlemek üzere Mann Whitney $U$ testi uygulanmıştır. Buna göre; bulunduğu kurum Uşak 
olanların okuma tutum genel puanları $(4,201 \pm 0,481)$, bulunduğu kurum Bilecik olanların okuma tutum genel puanlarından $(4,045 \pm 0,442)$ yüksek bulunmuştur. Bulunduğu kurum Uşak olanların okuma tutum genel puanları $(4,201 \pm 0,481)$, bulunduğu kurum Silivri olanların okuma tutum genel puanlarından $(3,935 \pm 0,626)$ yüksek bulunmuştur.

Araştırmaya katılan öğrencilerin alışkanlık puanları ortalamalarının bulunduğu kurum değişkeni açısından anlamlı bir farklılık gösterip göstermediğini belirlemek amacıyla yapılan test sonuçlarına göre grup ortalamaları arasındaki fark anlamlı bulunmamıştır ( $p>0.05)$.

\section{SONUÇ, TARTIŞMA VE ÖNERILER}

Bu araştırmada Açık Öğretim Lisesi Öğrencisi hükümlü ve tutukluların okumaya yönelik tutumları incelenmiştir. Araştırma bulguları, öğrencilerin okuma tutum düzeylerini, okuma tutum düzeyleri ile yaş, suç türü, nereli oldukları, medeni durum ve bulundukları ceza infaz kurumu değişkenleri arasındaki ilişkiyi nicel olarak araştırarak ortaya koymaktadır. Araştırmanın nitel kısmında öğrencilerin tutuklanma durumlarının, ceza infaz kurumları eğitim birimlerinin sağladığı imkânların, AÖL öğrencisi olmalarının, ceza infaz kurumu ortamında fazla vakte sahip olmaları ve kurum kütüphanelerinde bulunan kitap çeşitliliğinin okumaya yönelik tutumlarına nasıl bir etkisi bulunduğu tespit edilmiştir.

Araştırmada elde edilen bulgulara göre öğrencilerin "yarar" düzeyi çok yüksek $(4,329 \pm$ $0,631)$; "adanma" düzeyi yüksek $(3,753 \pm 0,795)$; "alışkanlık" düzeyi yüksek $(3,756 \pm 0,741)$; "gerçeği aşma" düzeyi çok yüksek $(4,238 \pm 0,840)$; "okuma tutum genel" düzeyi yüksek $(4,049$ $\pm 0,536)$; olarak saptanmıştır. Kapalı bir ortam olan ceza infaz kurumunda öğrencilerin yarar ve gerçeği aşma düzeylerinin çok yüksek oluşu kuruma bağlı özel şartlara bağlanabilir. Öğrencilerin kapalı kaldıkları ortamda boş vakitlerini okuyarak değerlendirmeleri yönüyle ve bulundukları ortamın sıkıntısından okuma sayesinde kurtularak gerçeği aşmaları, ortama daha rahat katlanabilmeleri, okumaya yönelik tutumlarında elde ettikleri yararlardır denilebilir. Öğrencilerin alışkanlık ve adanma düzeylerinin ve okuma tutumu genel düzeylerinin yüksek olma durumu, internet, telefon vb. iletişim araçlarının yasaklandığı kurumlarda boş vakitleri en iyi değerlendirme aracı olan okuma ile ve kurum eğitim birimlerinin hükümlü tutuklulara verdiği kütüphane, eğitim, okuma hizmetlerinin yeterli oluşuyla ilişkilendirilebilir. Lise öğrencilerinin okumaya yönelik tutumlarını incelemeye yönelik gerçekleştirilen çeşitli araştırmalarda farklı sonuçlar elde edilmiştir. Çeçen ve Deniz (2015) ile Baş (2012) ortaöğretim öğrencilerinin okumaya yönelik tutumlarının orta düzeyde olduğunu; Özdemir ve Akkaya (2013) ise yüksek düzeyde olduğunu tespit etmişlerdir. Ortaokul öğrencilerinin okumaya yönelik tutumlarının araştırıldığı çalışmalarda (Başaran ve Ateş, 2009; İşeri, 2010; Balcı, Uyar ve Büyükikiz, 2012 ve Durualp, Durualp ve Çiçekoğlu, 2013) öğrencilerin okumaya yönelik tutumlarının orta düzeyde olduğu görülmüştür. Üniversite öğrencilerinin okumaya yönelik tutumlarını araştıran araştırmacılar ise (Yılmaz ve Benli, 2010; Bozpolat, 2010 ve Kuzu, 2013) öğrencilerin okumaya yönelik tutumlarının orta düzeyde olduğunu ortaya koymuşlardır. Alan yazın incelendiğinde AÖL öğrencilerinin ve hükümlü tutuklu AÖL öğrencilerinin okumaya yönelik tutumlarını araştıran bir çalışmaya rastlanılmamıştır. Elde edilen araştırma sonucunda hükümlü tutuklu öğrencilerin okumaya yönelik tutumlarının yüksek oluşu, okumanın ceza infaz kurumlarında olumlu karşılanan bir etkinlik olduğunun göstergesi olarak görülebilir.

Çalışma sonucunda; 31-35 yaş olanların yarar puanları $(4,565 \pm 0,523), 25$ yaş altı olanların yarar puanlarından $(4,298 \pm 0,672)$ yüksek bulunmuştur. 31-35 yaş olanların yarar puanları $(4,565 \pm 0,523), 26-30$ yaş olanların yarar puanlarından $(4,250 \pm 0,678)$ yüksek bulunmuştur. 31-35 yaş olanların yarar puanları $(4,565 \pm 0,523), 36-40$ yaş olanların yarar puanlarından $(4,214 \pm 0,590)$ yüksek bulunmuştur. Bu bulgular ışı̆̆ında 31-35 yaş arasındaki 
öğrencilerin okumaya yönelik tutumlarının yarar boyutunda diğer öğrencilere göre daha olumlu olduğu görülmektedir.

Araştırmaya katılan öğrencilerin yarar, adanma, alışkanlık, gerçeği aşma, okuma tutum genel puanları ortalamalarının medeni durum ve suç türü değişkeni açısından anlamlı bir farklılık gösterip göstermediğini belirlemek amacıyla yapılan test sonuçlarına göre grup ortalamaları arasındaki fark anlamlı bulunmamıştır( $p>0.05)$.

Öğrencilerin bulundukları ceza infaz kurumu değişkeni doğrultusunda gerçekleştirilen analizler neticesinde adanma ve yarar boyutunda Uşak Kapalı Ceza İnfaz Kurumunda bulunan öğrencilerin puanları Bilecik ve Silivri 7 No'lu Ceza İnfaz Kurumunda bulunan öğrencilerin puanlarından yüksek olduğu tespit edilmiştir. Gerçeği aşma boyutunda yine Uşak'ta bulunan öğrencilerin puanlarının Bilecik'te bulunanlardan yüksek olduğu görülmüştür. Okumaya yönelik tutum genel puanında Uşak'ta bulunan öğrencilerin puanları Bilecik ve Silivri'de bulunanlardan yüksek olarak tespit edilmiştir. Alışkanlık boyutunda ise kurumlar arasında anlamlı bir farklılık bulunmadığı sonucuna ulaşımıştır. Okumaya yönelik tutumun bulunulan ceza infaz kurumuna göre değişmesi durumu kurumların eğitim birimlerinin verdikleri hizmete, doluluk oranlarına, kütüphanede bulunan kitap çeşitlerine, kurum idaresinin tutumundan personelin tutumuna kadar pek çok değişkenle açıklanabilir. Tüm bu değişkenlerin hükümlü tutukluların eğitimleri sürecinde, okumaya, kitaba, kütüphane hizmetlerine erişim süreçlerine etkisi bulunduğu düşünülmektedir.

Öğrencilerin nereli oldukları değişkeni doğrultusunda gerçekleştirilen inceleme sonucunda Akdeniz bölgesinden olan öğrencilerin adanma puanlarının Marmara ve Karadeniz bölgesinden olanlardan yüksek olduğu, Ege bölgesinden olan öğrencilerin adanma puanlarının Marmara ve Karadeniz bölgesinden olanların puanlarından yüksek olduğu, Güneydoğu Anadolu bölgesinden olanların adanma puanlarının Marmara ve Karadeniz bölgesi olanların puanlarından yüksek olduğu ortaya konulmuştur. Öğrencilerin yarar, alışkanlık, gerçeği aşma, okuma tutum genel puanları ortalamalarının memleket değişkeni açısından anlamlı bir farklılık gösterip göstermediğini belirlemek amacıyla yapılan test sonuçlarına göre grup ortalamaları arasındaki fark anlamlı bulunmamıştır ( $p>0.05)$.

AÖL öğrencisi hükümlü ve tutukluların okumaya yönelik tutumlarını belirlemeye yönelik gerçekleştirilen odak grup görüşmesinin analizleri neticesinde genel olarak tutuklanma durumundan sonra okumaya yönelik tutumun olumlu yöne çevrildiği sonucuna varılmıştır. Tutukluluk ve okuma ilişkisi alt başlığında okumanın hükümlü ve tutuklular için dış dünyaya açılan bir pencere niteliği taşıyabileceği düşünülmüştür. Ayrıca ceza infaz kurumlarında eğitim birimi çalışanları ve öğretmenleri tarafından sunulan eğitim hizmeti, kütüphane hizmeti gibi hizmetlerin öğrencilerin okumaya yönelik olumlu tutum geliştirmelerinde pozitif bir etki yarattığı sonucuna varılmıştır.

Ceza infaz kurumu eğitim birimi çalışmaları ve okuma ilişkisi bağlamında okumaya yönelik tutumun değerlendirilmesi sonucu, Ceza Tevkifevleri Genel Müdürlüğünün direktifleri doğrultusunda eğitim birimleri tarafından gerçekleştirilen eğitim faaliyetlerinin öğrencilerin okumaya yönelik tutumlarında büyük bir önemi olduğu söylenebilir. Kurum idareleri, öğrencilere gelen kitapları yasaklı bulunmamak kaydıyla hükümlü tutuklulara teslim etmekte, onların istedikleri kitapları yayınevlerinden temin etmelerini sağlamaktadır. Bu türden hizmetlerin kurum eğitim birimleri tarafından sunulması, hükümlü ve tutuklu öğrencilerin okumaya yönelik olumlu tutum geliştirmelerine katkıda bulunmaktadır. Ergin (2012), Türkiye'deki bir kadın ve bir erkek cezaevindeki eğitim programları hakkında cezaevi eğitmenleri ve cezaevi sakinlerinin algılarını keşfetmeyi ve bu algıları karşılaştırmayı hedefleyen araştırması sonucunda hem cezaevi eğitimcilerinin hem de hükümlü tutukluların cezaevindeki 
eğitim programlarının pozitif yönde sosyal, psikolojik etkileri bulunduğunu bu etkinin tahliye sonrasında da onları olumlu yönde etkileyeceği görüşünde olduklarını tespit etmiştir. Ayyıldız (2008) hükümlülerin cezaevi eğitim programları hakkındaki görüşlerini araştırdığı çalışmasında kendilerine olan güvenin artması, daha olumlu hissetme, geleceğe dair planlar yapıp amaç belirleme ve öğrenmenin ortaya çıkan etkiler olduğunu ve hükümlülerin çoğunluğunun eğitim programlarının gelecekteki planlarını gerçekleştirmede yardımcı olacağını düşündüklerini ortaya koymuştur. Bu bulgular ve bizim çalışmamızın ışı̆̆ında ceza infaz kurumları eğitim birimi çalışmalarının olumlu yönde önemli katkıları olduğu söylenebilir.

Hükümlü ve tutukluların AÖL öğrencisi olmalarının okumaya yönelik tutumlarına etkisine bakıldığında yine tüm hükümlü tutukluların olumlu yönde etkisi olduğu fikrinde birleştikleri tespit edilmiştir.

Tutuklu hükümlü olmaya bağlı vakit ve okuma ilişkisi bağlamında okumaya yönelik tutumun yine olumlu yönde etkilendiği sonucuna varılmıştır. Hükümlü ve tutuklu öğrencilerin kendi ifadelerinden sosyo-ekonomik bakımdan sıkıntılı bölgeler olan Bahçelievler Yayla; Büyükçekmece Karagümrük; Esenler Otogaraltı, Şişli Kuştepe, Beyoğlu Tarlabaşı gibi semtlerde büyüdükleri, bu semtlerde daha ilkokulda iken okumaya teşvik edilmek yerine okuyanın ötelendiği, öğrencilerin mahallelerde yaşanan grup kavgalarına karşı kendilerini nasıl koruyacaklarına dair telkinlerle büyütüldükleri tespit edilmiştir. Bu tespitler doğrultusunda bireylerin okumaya yönelik tutumlarında bulundukları aile, mahalle, çevre gibi faktörlerin etkili olduğu söylenebilir. Bulundukları çevrelerde okumaya yönelik hiçbir olumlu yönlendirme almayan öğrencilerin tutumlarının, ceza infaz kurumlarında kaldıkları süre içerisinde gerçekleştirilen eğitim faaliyetleri, boş zamanlarının fazla oluşu gibi etkenlere bağlı olarak olumlu hâle geldiği söylenebilir.

Ceza infaz kurumu kütüphanelerinin okumaya yönelik olumlu yönde tutum geliştirilmesine büyük katkısı olduğu odak grup görüşmesine katılan tüm öğrencilerin ortak fikri olarak tespit edilmiştir. Mahpusluk-okuma-duygu ilişkisi ışığında okumaya yönelik tutum değerlendirildiğinde öğrencilerin tamamında okuma tutumunun olumlu yönde olduğu tespit edilmiştir. Öğrenciler için okumanın, mahpusluk hâlini unutmanın bir yolu, dış dünyaya açılan bir pencere durumu, sıkıntıyı azaltan bir faktör, gerçeği, mekânı aşma aracı olarak görüldüğü söylenebilir.

Ceza infaz kurumları hükümlü ve tutukluların yalnızca barındırıldıkları mekânlar değil aynı zamanda ıslah ve eğitim çalışmalarının etkin bir şekilde yürütüldüğü kurumlardır. Bu yönüyle düşünüldüğünde okumaya yönelik tutumun olumlu şekilde geliştirilmesi, eğitimin ve ıslahın hedeflenen seviyeye eriştirilmesinde eğitim birimleri ve kütüphanelerin faaliyetleri büyük önem arz etmektedir. Kütüphanelerde çalışan görevlilerin infaz ve koruma memurları arasından seçilmesi yerine bilgi ve belge yöneticisi uzmanların atanması yerinde bir uygulama olacaktır.

Kütüphanelere sağlanacak kitapların alımı hususunda bakanlık tarafından bir bütçe ayrılmadığı için sivil toplum kuruluşları, yayınevleri, yazarlar, üniversiteler sosyal sorumluluk projeleri yaparak kurumlarda okumaya yönelik tutumun olumlu yönde geliştirilmesi için yardımcı olmalıdırlar.

Ceza infaz kurumlarında okumaya yönelik tutum olumlu yöne evrilerek bibliyoterapi uygulamaları yani doğru zamanda, doğru bireyle doğru kitabın buluşturulması gerçekleştirilmelidir. "Sözcüğün içerisinde terapi kavramının yer alması, bu yaklaşımın yalnızca psikolojiyle ilgili klinik bir uygulama olduğu izlenimini vermemelidir. Aslında yapılan, doğru zamanda doğru kişiyle, doğru kitabı buluşturarak onun rahatlamasına yardımcı olabilmektir." (Philpot, 1997'den akt. Öner, 2007: 136). Okuma etkinlikleri ile rahatlayan hükümlü ve 
tutuklular ruhsal bakımdan bir arınma gerçekleştirip cezaevinde bulunduğu sırada daha uyumlu yaşayabilir, tahliyeleri sonrasında topluma ruh sağlığı yerinde olarak dönebilirler.

\section{KAYNAKLAR}

Akkaya, N. ve Özdemir, S. (2013). Ortaöğretim öğrencilerinin okumaya yönelik tutumlarının incelenmesi (İzmir-Buca örneği). Bartın Üniversitesi Eğitim Fakültesi Dergisi. 2(1), 75-96.

Akşit, B.T. (1992). "Medikal araştırmalarda etik sorunlar", Türk Tabipler Birliği Sağlık Kongresi. 8-11 Mart 1992. Shareton Oteli. Ankara.

Akyol, H. Başaran, M.(2009). Okuduğunu Anlama ve metne karşı geliştirilen tutum üzerinde metnin bilgi verici veya hikâye edici olmasının etkisi. Uşak Üniversitesi Sosyal Bilimler Dergisi, (2)1, 11-23,

Allport G. W. (1967). Readings in attitude theory and measurement. Martin Fishbein (Ed.), in Attitudes (pp. 1-14). New York: John Wiley\&Sons.

Arı, E. ve Demir, M. K. (2013). Illköğretim bölümü öğretmen adaylarının kitap okuma alışkanlıklarının değerlendirilmesi. Ana Dili Eğitimi Dergisi, (1)1, 116-128.

Aydın, i. S. , Kaya, N. S. ve Bayraktar, U. (2015). Türkçe öğretiminde öğrenci tutumlarına yönelik yazılan makaleler üzerine meta-analiz çalışması. International Journal of Languages' Education and Teaching, 3/2, 95-118.

Ayyıldız, G. G. (2008). Hükümlülerin cezaevi eğitim programları hakkındaki görüşleri. Yayımlanmamış Yüksek Lisans Tezi, Boğaziçi Üniversitesi, Sosyal Bilimler Enstitüsü, İstanbul.

Balcı, A. (2009). Illköğretim 8. sınıf öğrencilerinin kitap okuma alışkanlığına yönelik tutumları. Mustafa Kemal Üniversitesi Sosyal Bilimler Enstitüsü Dergisi, (6)11, 265-300.

Balcı, A, Uyar, Y. ve Büyükikiz K. K. (2012). İlköğretim 6. sınıf öğrencilerinin okuma alışkanlıkları, kütüphane kullanma sıklıkları ve okumaya yönelik tutumlarının incelenmesi. Turkish Studies, (7)4, 965-985.

Baş, G. (2012). Reading attitude of high school students: An analysis from different variables. International Journal on New Trends in Education and Their Implications, 3 (2), 47-58.

Başaran, M. Ateş, S. (2009). İlköğretim beşinci sınıf öğrencilerinin okumaya ilişkin tutumlarının incelenmesi. Gazi Eğitim Fakültesi Dergisi, (29)1, 73-92.

Baştuğ, M., Keskin, H. K. (2013). Ergenlik dönemi okuma tutumu ölçeğinin Türkçeye uyarlanması. Turkish Studies, (8)4, 295-311.

Büyüköztürk, Ş. (2013). Sosyal bilimler için veri analizi el kitabı. Ankara: Pegem Akademi Yayıncılık.

Creswell, J. W. (2013). Araştırma deseni nitel, nicel ve karma yöntem yaklaşımları (Çeviri editörü: Demir, Selçuk Beşir). Ankara: Eğiten Kitap.

Çeçen, M. A. ve Deniz, E. (2015). Lise öğrencilerinin okumaya yönelik tutumları (Diyarbakır ili örneği). Mustafa Kemal Üniversitesi Sosyal Bilimler Enstitüsü Dergisi, 12/30, 193-312.

Dedeoğlu, H., Ulusoy, M. (2013). Sınıf öğretmeni adaylarının okuma tutumları. Okuma Yazma Eğitimi Araştırmaları, (1)2, 80-88.

Demir, G. (2011). Ceza infaz kurumu kütüphaneleri ve Türkiye'de durum. Yayımlanmamış Doktora Tezi, İstanbul Üniversitesi, Sosyal Bilimler Enstitüsü, İstanbul.

Demirel, Ö. ve Ün, K. (1987). Eğitim terimleri sözlüğü. Ankara: Şafak Matbaası.

Dey, I. (1993). Qualitative data analysis: A user-friendly guide for social scientists. London: Routledge. 
Erdem, ì. ve Altunkaya, H. (2013). Silivri ceza infaz kurumları yerleşkesinde bulunan açık öğretim ortaokulu öğrencisi hükümlü ve tutukluların okuma alışkanlıkları. Adıyaman Üniversitesi Sosyal Bilimler Enstitüsü Dergisi Türkçenin Eğitimi Öğretimi Özel Sayısı, 11, 453-489.

Ergin, H. (2012). Türk cezaevlerindeki eğitim programlarının bir analizi: Cezaevi eğitmenleri ve cezaevi sakinlerinin algıları. Yayımlanmamış Yüksek Lisans Tezi, Boğaziçi Üniversitesi, Sosyal Bilimler Enstitüsü, İstanbul.

Epçaçan, C. (2013). Sokrat semineri tekniğine dayalı öğretimin öğrencilerin okuduğunu anlama becerisine ve okumaya ilişkin tutuma etkisi. Akademik Araştırmalar Dergisi, 1(58), 93-116.

Goodson, I., \& Walker, R. (2005). Putting life into educational research. In R. R. Sherman \& R. B. Webb (Eds.). Qualitative research in education: Focus and Methods (pp. 108-121). London: RoutledgeFalmer.

Gömleksiz, M. N. (2004). Kitap okuma alışkanlığına ilişkin bir tutum ölçeğinin geçerlik ve güvenirliği. FIrat Üniversitesi Sosyal Bilimler Dergisi, (14)7, 185-195.

Iflazoğlu Saban, A., Ayçin, A. A. (2011). İncele-sorgula-oku-tekrar et-gözden geçir tekniğinin beşinci sınıf öğrencilerinin okuduğunu anlama başarısı ve okumaya yönelik tutumları üzerine etkisi: Yibo örneği. Muğla Üniversitesi Sosyal Bilimler Enstitüsü Dergisi, (1)26, 197-228.

İnceoğlu, M. (2010). Tutum, algı, iletişim. 5. Baskı. İstanbul: Beykent Üniversitesi Yayınları. No 69.

İşeri, Kamil. (2010). ilköğretim ikinci kademe öğrencilerinin okuma tutumlarının incelenmesi. Uluslararası Insan Bilimleri Dergisi, (7)2, 468-487.

Jeong, J. (2004). Analysis of the factors and the roles of hrd in organizational learning styles as identified by key informants at selected corporations in the republic of Korea. Unpublished PhD thesis, Texas A \& M University. Major Subject: Educational Human Resource Development, Amerika.

Kağıtçıbaşı, Ç. (1999). Yeni insan ve insanlar. İstanbul: Evrim Yayınevi.

Kanmaz A., Saracaloğlu, A. S. (2012). Okuduğunu anlama stratejisi kullanımının okumaya yönelik tutum ve kalıcılığa etkisi. NWSA e-Journal of New World Sciences Academy, 7/2,764-776.

Karasar, N. (2008). Bilimsel araştırma yöntemi. 18. Baskı. Ankara: Nobel Yayın Dağıtım.

Koçak, B., Kurtlu, Y., Ulaş, H., Epçaçan, C. (2015). Sınıf öğretmeni adaylarının eleştirel düşünme düzeyleri ve okumaya yönelik tutumları arasındaki ilişki. Ekev Akademi Dergisi, (19) 61, 211228.

Krueger, R.A. (1998). Moderating focus groups. California: SAGE.

Öner, U. (2007). Bibliyoterapi. Çankaya Üniversitesi Fen-Edebiyat Fakültesi, Journal of Arts and Sciences, 7, 133-150.

Özbay, M., Uyar, Y. (2009). İlköğretim ikinci kademe öğrencileri için okumaya yönelik tutum ölçeğinin geliştirilmesi: Geçerlilik ve güvenirlik çalışması. E-Journal Of New World Sciences Academy, (4)2, 632-651.

Özdemir, S. (2013). Ortaöğretim öğrencilerinin okuma alışkanlık ve tutumlarıyla fen, matematik derslerindeki akademik başarıları arasındaki ilişkinin incelenmesi (i̇zmir Buca ilçesi örneği). Yayımlanmamış Doktora Tezi, Dokuz Eylül Üniversitesi, Eğitim Bilimleri Enstitüsü, İzmir.

Özdemir, S. ve Akkaya, N. (2014). Ortaöğretim öğrencileri için okumaya yönelik tutum ölçeği, geçerlik ve güvenirlik çalışması. Milli Eğitim, 43(203), 55-73.

Sallabaş, M. E. (2008). İlköğretim 8. sınıf öğrencilerinin okumaya yönelik tutumları ve okuduğunu anlama becerileri arasındaki ilişki, Inönü Üniversitesi Eğitim Fakültesi Dergisi, (9)16, 141-155. 
Sarar, Kuzu, T. (2013). Öğretmen adaylarının okumaya karşı tutumları ile genel kültür düzeyleri arasındaki ilişkinin değerlendirilmesi. Dil ve Edebiyat Eğitimi Dergisi, (2)6, 55-72.

Susar, Kırmızı, F., Güneş, F. (2014). E-Kitap okumaya yönelik tutum ölçeğinin(ekot) geliştirilmesi: Geçerlilik ve güvenirlik çalışması. Bartın Üniversitesi Eğitim Fakültesi Dergisi, (3)2, 196-212.

Temizkan, M. (2008). Türkçe öğretmeni adaylarının öğretmenlik mesleğine yönelik tutumları üzerine bir araştırma. Türk Eğitim Bilimleri Dergisi. 6(3), 461-486.

Türkyılmaz, M., Aydemir, Y. (2014). Ortaöğretim öğrencilerinin okumaya yönelik tutumlarını belirleme ölçeği geçerlik ve güvenirlik çalışması. International Journal Of Language Academy, (2)3, 194-207.

Yalınkılıç K. (2007). Türkçe öğretmen adaylarının okumaya ilişkin tutum ve görüşleri. Uluslararası Sosyal Araştırmalar Dergisi, (1)1, 225-241.

Yaman, H. ve Dağtaş, A. (2013). Ekrandan okumanın okumaya yönelik tutuma etkisi. Eğitimde Kuram Ve Uygulama Dergisi, (9)4, 314-333.

Yıldırım, A., Şimşek, H. (2013). Sosyal bilimlerde araştırma yöntemleri (9. Baskı). Ankara: Seçkin Yayıncilık.

Yılmaz, M., Benli, N. (2010). Sınıf öğretmeni adaylarının okuma alışkanlığına yönelik tutumlarının bazı değişkenlere göre incelenmesi. Erzincan Eğitim Fakültesi Dergisi, (12)1, 281-291.

http://www.aol.meb.gov.tr/aolsayisalveriler.php?cgl=8 adresinden 27/01/2016 tarihli erişim ile alınmıştır.

http://www.cte.adalet.gov.tr/ adresinden 27/03/2016 tarihli erişim ile alınmıştır.

http://www.istatistikanaliz.com/faktor_analizi.asp 27/03/2016 tarihli erişim ile alınmıştır.

\section{SUMMARY}

This study is intended to identify the level of reading attitudes of convict and arrested students in Distance Secondary School Education, based on different variables. The study is conducted according to a mixed survey model where quantitative and qualitative data analysis techniques are employed together. The study used the screening method of quantitative survey methods and focus group interview technique of the quantitative survey methods. The study group in the survey is made up of a total of 211 convict and arrested students in Distance Secondary School Education; 78 from Silivri No.7 Type L Closed Prison, 73 from Bilecik Type M and 67 from Uşak Type E Closed Prisons. Quantitative data is obtained via the "Attitude Towards Readindg Scale" developed by Özdemir and Akkaya (2014) and "Personal Data Form" while the qualitative data is obtained through the focus group interview. SPSS 22 data analysis program is employed in the analysis of quantitative data while content analysis method is used in the analysis of the qualitative data.

Open Education High School (AOL) is a system providing high school education by using distance learning technologies and it was established in 1992 within the Lifelong Learning General Directorate. Active number of students registered in AOL for the first term of 2015-2016 academic year is 1.026.782, with 592.308 female and 434.474 male(http://www.aol.meb.gov.tr/aolsayisalveriler.php?cgl=8). A certain part of these students consist of convicts and inmates in penal institutions of Ministry of Justice. Within the country, convicts and inmates are being trained in accordance with circular no 46/1. It can be said that the success of such education is closely related with the students' attitude towards reading.

The cognitive, sensual and behavioral manner of individuals towards an event, status or individual constitute the attitude. When faced with an event, situation or person; the individual first creates an idea with the combination of cognitive and sensual characteristics; and the behavioral reveal of this idea indicates his/her attitude. Reintegrating the convicts and inmates to the society and to prevent them committing crimes again is only possible through education. The enhancement of convicts 
and inmates' attitude towards reading via the education, and get them adopt the reading habit is very important. It has been considered that the attitude of students towards reading has to be learned in order to implement such education.

According to the findings of study, the level of "benefit" for students is very high $(4,329 \pm$ $0,631)$; the level of "commitment" is high $(3,753 \pm 0,795)$; the level of "habituality" is high $(3,756 \pm$ $0,741)$; the level of "surpassing the reality" is very high $(4,238 \pm 0,840)$; and the level of "reading attitude general" is high $(4,049 \pm 0,536)$. Very high levels of benefit and surpassing the reality in a closed environment such as penal institution depends on the special conditions of it.

As a result of study; the benefit scores of those between the ages $31-35(4,565 \pm 0,523)$ were higher than those below $25(4,298 \pm 0,672)$. The benefit scores of those between the ages 31-35 $(4,565 \pm 0,523)$ were higher than those between the ages $26-30(4,250 \pm 0,678)$. The benefit scores of those between the ages $31-35(4,565 \pm 0,523)$ were higher than those between the ages 36-40 $(4,214 \pm 0,590)$.

As a result of the analyses conducted in accordance with the penal institution variable; the commitment and benefit scores of students in Usak Closed Prison were higher than those in Bilecik and Silivri No.7 Penal Institutions. It is also seen that the surpassing the reality scores of students in Usak were higher than those in Bilecik. In terms of scores for attitude towards reading; it has been determined that the scores of students in Usak were higher than those in Bilecik and Silivri. It has been concluded that there is no significant difference between the institutions in terms of habit.

As a result of review depending on the homeland variable of students; it was seen that the students from Mediterranean region had higher commitment scores than those from Marmara and Black Sea regions; the commitment scores of students from the Aegean region were higher than those from Marmara and Black Sea regions; and the commitment scores of those from Southeastern Anatolia were higher than those from Marmara and Black Sea regions. According to the results of the test implemented in order to find whether the benefit, habit, surpassing the reality and reading attitude general score averages had a significant difference in terms of their homeland or not; no significant difference was seen ( $p>0.05)$.

As a result of focus group interviews implemented in order to determine the attitude of AOL student convicts and inmates towards reading; it has been concluded that the attitude towards reading has turned to become positive after arrest. In the sub-heading of "conviction and reading relation"; it was considered that reading could be a window opening to the outside world for convicts and inmates. Also, it has been concluded that the training services, library services etc. provided by the staff and teachers of education unit in penal institutions had a positive impact on students' attitude towards reading.

Penal institutions are not the institutions where convicts and inmates are accommodated only; but those places are where the activities of correction and education is an ongoing process. Considering from this point, improving the attitude towards reading in a positive way will serve the education and correction to reach at aimed level. Convicts and inmates may be relieved through reading activities, purified spiritually and live more compatible during their period in prison; therefore may be reintegrated into the society with better spiritual conditions. 